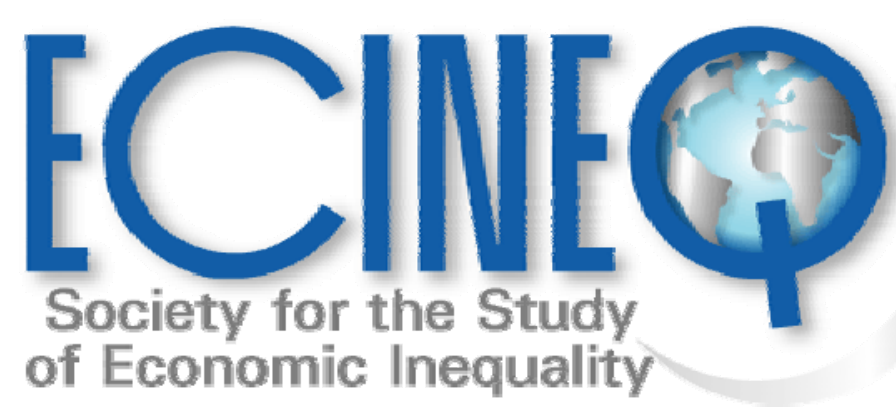

Working Paper Series

\title{
Taking care of your own: Ethnic and religious heterogeneity and income inequality
}

Oguzhan C. Dincer

Peter J. Lambert 


\title{
Taking care of your own: Ethnic and religious heterogeneity and income inequality
}

\author{
Oguzhan C. Dincer ${ }^{\dagger}$ \\ MasseyUniversity \\ Peter J. Lambent ${ }^{\ddagger}$ \\ Univesity of Oregon
}

\begin{abstract}
Using recently developed indices of fractionalization and polarization, we analyze the direct and indirect effects of ethnic and religious heterogeneity on income inequality and on welfare programs across US states. We find strong evidence (1) that there is a positive relationship between ethnic and religious polarization and income inequality and an inverse-U shaped relationship between ethnic and religious fractionalization and income inequality; and (2) that there is a negative relationship between ethnic and religious polarization and monthly welfare payments under the AFDC/ TANF scheme, and a Ushaped relationship between ethnic and religious fractionalization and the AFDC/ TANF payments.
\end{abstract}

Kegwords E thnic and Religious Heterogeneity, Income Inequality JEL Classification D 31, J15, 015

\footnotetext{
* The authors wish to thank Ron D avies for helpful comments on an earlier draft of this paper.

${ }^{\dagger}$ Massey University, Private Bag 102904, North Shore Mail Centre, Auckland, New Zealand, Email: o.c.dincer@massey.ac.nz, Fax: 6494418177

¥Address:D epartment of Economics, University of O regon, Eugene, OR 97403-1285, USA, Email: plambert@ uoregon.edu, Fax: 5413461243
} 


\section{Taking care of your own:}

\section{Ethnic and religious polarization and income inequality}

\section{Introduction}

Several empirical studies, based on cross country regressions, such as, Alesina et al. (2003) and Montalvo and Reynal-Querol (2005) show that ethnic and religious heterogeneity generate conflicts leading to poor quality of institutions, poorly designed policies and poor growth performances. Alesina et al. (2003), for example, measure heterogeneity by using a fractionalization index $(F I)$ calculated as

$$
F I_{i}=1-\sum_{j=1}^{J} n_{i j}^{2}
$$

where $n_{i j}$ is the population share of group $j$ in country $i$. The fractionalization index gives us the probability that two randomly selected individuals in a country belong to two different ethnic or religious groups. It reaches a maximum if every individual in a country belongs to a different ethnic or religious group. Alesina et al. (2003) find that going from complete ethnic homogeneity to complete ethnic heterogeneity decreases the growth rate of income by almost 2 percentage points. Montalvo and Reynal-Querol (2000, 2005), on the other hand, use a polarization index $(P I)$ to measure heterogeneity:

$$
P I_{i}=1-\sum_{j=1}^{J}\left(\frac{0.5-n_{i j}}{0.5}\right)^{2} n_{i j} .
$$

$P I$ is an index that measures the distance of any distribution of ethnic and religious groups from the situation that leads to the maximum conflict. The closer is the distribution of religious and ethnic groups in a country the higher is the $P I$. In a country with three ethnic or religious groups distributed with percentages 45,45 and 10, the index and hence the likelihood of conflict is 
higher than with the percentages 34, 33 and 33 or with 90, 10, 0 (Reynal-Querol and Montalvo 2000, and Montalvo and Reynal-Querol 2005). In contrast to FI, PI reaches a maximum when there are two religious or ethnic groups of equal size in a country. They find that going from complete homogeneity to complete heterogeneity decreases the growth rate of income by almost 1 percentage point.

Ethnic and religious heterogeneity not only affect the growth rate of income, they also affect income inequality both directly and indirectly. First, as Glaeser (2005) argues, ethnic heterogeneity causes skill inequality. "Skill inequality seems to come mostly from juxtaposition of ethnic groups with different educational traditions ... (Glaeser 2005, 6)" Protestant churches, for example, as opposed to Catholic church, traditionally encourage education to increase familiarity with the Bible (Glaeser 2005). Second, ethnic heterogeneity limits the tendency to redistribute income. According to Alesina and Glaeser (2004), this is because individuals who belong to one ethnic group are less willing to support redistribution helping other ethnic groups. The members of different ethnic groups simply view one another as direct competitors for scarce economic resources (Bobo and Kluegel 1993, Bobo and Hutchings 1996).

There are several empirical studies which investigate the effects of ethnic heterogeneity on redistribution channels using micro data. Luttmer (2001), for example, uses survey data to investigate the determinants of individual support for welfare programs in US and finds strong empirical evidence showing a clear pattern of ethnic group loyalty. He finds that, an additional black welfare recipient reduces support for welfare by non-black respondents but has little effect on black respondents. Conversely, an additional non-black welfare recipient reduces black support for welfare but has little effect on non-black support. Again using survey data, Okten and Osili (2004) investigate the determinants of contributions in Indonesia to community organizations, another important redistribution channel, and find similar results. They find that 
households are less likely to contribute to community organizations if they belong to a nonmajority group. Their results partially support Alesina and La Ferrara's (2000) hypothesis that the members of the non-majority ethnic group derive positive utility from interacting with the members of the same ethnic group and negative utility from interacting with the members of the majority ethnic group. Among the few studies using macro data, Alesina and Glaeser (2004) find that ethnic fractionalization reduces support for welfare programs across countries.

Although the above mentioned studies present persuasive evidence regarding the effects of ethnic and religious heterogeneity on redistribution of income and channels of redistribution, to our knowledge there are no studies attempting to find the magnitude of the direct and indirect effects of ethnic and religious heterogeneity on income inequality. In other words, there are not any studies attempting to answer such questions as: how many percentage points of the difference in Gini coefficients between two countries or two states are explained by ethnic and religious heterogeneity?

In this study, we first analyze the direct effects of ethnic and religious heterogeneity on income inequality, using both of the aforesaid polarization and fractionalization indices and data for 50 US states. As Bobo and Hutchings (1996) argue, due to ongoing immigration from Asia, South America and Central America and the earlier internal migration of African Americans, most, if not all, of the states in the US today are significantly multi-ethnic and multi-religious conglomerations. The average value of the ethnic (religious) polarization index for 1980 and 1990 is 0.48 (respectively, 0.58) and the average value of the ethnic (religious) fractionalization index for the same years is 0.28 (respectively, 0.69) across 50 states. US states provide an ideal setting to analyze the effects of ethnic and religious heterogeneity since there are much better and more comparable data on ethnic and religious heterogeneity as well as on 
such control variables as unemployment insurance, minimum wage, and unionization rate than across countries (Alesina and LaFerrara 2005).

We find a linear and positive relationship between ethnic and religious heterogeneity and income inequality when we use the polarization index as our measure of heterogeneity. According to our seemingly unrelated regression (SUR) estimates, going from complete ethnic (religious) homogeneity (an index of 0 ) to complete ethnic (religious) heterogeneity (an index of 1) increases the Gini coefficient by almost 3 (respectively, 3) percentage points. When we use the fractionalization index as our measure of heterogeneity, we find inverse-U shaped relationships between both ethnic and religious heterogeneity and income inequality. In other words, we find that there are inequality maximizing levels of fractionalization. According to our SUR estimates, the Gini coefficient is maximized when ethnic (religious) fractionalization is equal to 0.62 (respectively, 0.54 ).

Second, we analyze the indirect effects of ethnic and religious heterogeneity on income inequality, by focusing on their effects on welfare programs using macro data. One of the biggest welfare programs in the US is the AFDC/TANF (Aid to the Families with Dependent Children/Temporary Assistance to Needy Families) scheme. The results of the SUR estimation for $A F D C / T A N F$ scheme mirror those pertaining to the relationship between ethnic/religious fractionalization/polarization and the Gini coefficient. We find linear and negative relationships between ethnic and religious polarization indices and $A F D C / T A N F$ payments and U-shaped relationships between ethnic and religious fractionalization indices and $A F D C / T A N F$ payments. According to our estimates going from complete ethnic (religious) homogeneity to complete ethnic (religious) heterogeneity causes monthly $A F D C / T A N F$ payments to decrease by $\$ 196$ (respectively, \$208). AFDC/TANF payments are minimized when ethnic (religious) fractionalization is equal to 0.50 (respectively, 0.63 ). 
The study is organized as follows. Section 2 presents the data on ethnic and religious heterogeneity as well as on the control variables. Section 3 presents the results of the SUR estimation and discusses the direct and indirect effects which ethnic and religious heterogeneity have on income inequality. Section 4 concludes.

\section{Data}

The data we use to calculate the ethnic polarization and fractionalization indices (henceforth EPI and EFI) are from the Census Bureau for the two years 1980 and 1990, and for six ethnic groups: Hispanics, Whites, Blacks, American Indian and Eskimos, Asians, and Others. The data we use to calculate the religious polarization and fractionalization (henceforth $R P I$ and $R F I$ ) indices are from the American Religion Data Archive for the same two years. These data are collected by representatives of the Association of Statisticians of American Religious Bodies to provide information on the number of churches and adherents for 111 Judeo-Christian church bodies for 1980 and 133 Judeo-Christian church bodies for 1990. For consistency, we exclude the church bodies which are not covered in both time periods. The adherent totals of the religious groups include almost $50 \%$ of the total population in both time periods. Unfortunately, we do not have data on other religious groups such as Muslims and Hindus, nor on non-religious groups. Nevertheless, since the Muslim population is estimated to be lower than 1 percent of the total population and the Hindu population is estimated to be even lower than that, we do not believe that missing information on such religious groups is critical for our study. According to the National Survey of Religious Identification (NSRI) conducted in 1990 by Barry A. Kosmin, Seymour P. Lachman and associates at the Graduate School of the City University of New York, the Muslim population is estimated to be 0.5 percent of the total population, whilst the Buddhists account for 0.4 percent, the Unitarian Universalists 0.3 
percent, and the Hindus 0.2 percent. Non-religious groups are estimated to be 7.5 percent of the total population.

Taking the polarization indices first, we find that, among the four census regions, the South is the most polarized, both ethnically and religiously: EPI is maximal equal to 0.91 in Mississippi, and $R P I$ is maximal and equal to 0.79 in Louisiana (these are averages across the two years 1980 and 1990). The least ethnically polarized region is Northeast: $E P I=0.06$ in Vermont. West is the least religiously polarized region: $R P I=0.30$ in Utah. Not surprisingly, there is a significant correlation between $E P I$ and $R P I$ : the correlation coefficient is equal to 0.36. Figure 1 shows the relationship between $E P I$ and $R P I$ for 50 states averaged across the two years 1980 and 1990.

Turning to the fractionalization indices, we find that the South is the most ethnically fractionalized region while Midwest is the least so: $E F I=0.47$ in Mississippi, and $E F I=0.07$ in Iowa, one of the least ethnically fractionalized states. Surprisingly, the most religiously fractionalized region is Midwest: $R F I=0.84$ in Iowa. Northeast is the least religiously fractionalized region: $R F I=0.29$ in Rhode Island. The correlation between $E F I$ and $R F I$ is negative and quite low: the correlation coefficient is equal to -0.06. Figure 2 shows the relationship between $E F I$ and $R F I$ for the same 50 states and the same two years as used in the construction of Figure 1.

The relationship between the polarization and fractionalization indices is quite important. As mentioned earlier, PI reaches a maximum when there are two religious or ethnic groups of equal size in a country. FI, on the other hand, increases with the number of groups. Figure 3 is taken from of Montalvo and Reynal-Querol (2005) and shows FI and PI as functions of the number of groups (assumed of equal size). Figure 4 and Figure 5 show the relationships we find between $E P I$ and $E F I$, and between $R P I$ and $R F I$ respectively for 50 US 
states. These plots are quite similar in nature to those to be found in Montalvo and ReynalQuerol (2005) for 138 countries. For low levels of fractionalization, PI and FI are highly and positively correlated. For medium levels of fractionalization, the correlation is zero, and for high levels of fractionalization it is negative. Figures $\mathbf{4 a - 4 d}$ and $\mathbf{5 a - 5 d}$ show the relationships between $E P I$ and $E F I$ and between $R P I$ and $R F I$ in 4 census regions, respectively. Although the relationship between $E P I$ and $E F I$ does not change significantly across regions, the one between $R P I$ and $R F I$ does. In the Midwest, the most religiously fractionalized region, there is a negative relationship between $R P I$ and $R F I$ while in the Northeast, the least fractionalized region, there is a positive relationship between the two. It is not surprising, then, to observe that the relationship between fractionalization and income inequality and the relationship between polarization and income inequality are rather different.

To measure income inequality across states we use Gini coefficients given by the Census Bureau for 1989 and 1999. Based on the averages across the two years Alaska has the lowest Gini coefficient and Texas the highest. The states with 5 lowest and highest Gini coefficients as well those with 5 lowest and highest religious/ethnic polarization/fractionalization indices are given in Table 1. As expected, the correlations between $E P I$ and the Gini coefficient and between RPI and the Gini coefficient are positive: the correlation coefficients are 0.55 and 0.39, respectively. Figure 6 and Figure 7 show the positive relationships between the polarization indices and the Gini coefficient. The relationships between the fractionalization indices and the Gini coefficient, on the other hand have inverse-U shapes as shown in Figure 8 and Figure 9. The correlation coefficient between $E F I$ and the Gini coefficient is 0.45 and that between $R F I$ and the Gini coefficient is -0.08 . Pairwise correlations of the fractionalization and the polarization indices and the Gini coefficient are given in Table 2. 
We include a set of control variables in our regressions to minimize the omitted variable bias. First, following Wu, Perloff, and Golan (2005), we include a set of government policy variables: Minimum Wage, Unemployment Insurance, and AFDC/TANF. Our Minimum Wage data are from Neumark and Nizalova (2004). Both Unemployment Insurance and AFDC/TANF data are from the Green Book (Background Material and Data on Major Programs within the Jurisdiction of the Committee on Ways and Means). We use real values of the hourly minimum wage, weekly maximum unemployment insurance benefits and the maximum monthly benefits for a single parent three person families covered under the $A F D C / T A N F$ scheme. Second, we include two macroeconomic variables: average growth rate of real per capita Gross State Product (GSP) and the unemployment rate (Unemployment Rate) each averaged across the two sub-periods 1980-1989and 1990-1999. The GSP data are from the Bureau of Economic Analysis (BEA) and the unemployment data are from Bureau of Labor Statistics (BLS). Third, again following $\mathrm{Wu}$, Perloff, and Golan (2005) we include a set of demographic variables: the percentage of female headed families (Female Head), the percentage of the population under age 18 (Young), the percentage over age $65($ Old $)$, and the percentage of the population age 25 and above with a college degree or more education (College). As Glaeser (2005) argues, stronger unions generally mean increased equality. Hence we include the unionization rate (Union) as another control variable using the estimates provided by Hirsch, Macpherson, and Vroman (2001). Finally, following Li et al. (2000) and Gupta et al. (2002) we include Corruption as our last control variable. Both of the studies find strong empirical evidence of a positive relationship between inequality and corruption. ${ }^{1}$ As our measure of corruption, we use

\footnotetext{
${ }^{1}$ Tanzi (1995) argues that, corruption is a factor distorting the redistributive role of government. Since only the better connected individuals get the most profitable government projects, it is less likely that the
} 
the number of government officials convicted in a state for crimes related to corruption. The data are from the Justice Department's "Report to Congress on the Activities and Operations of the Public Integrity Section”. These data are used by several studies such as Goel and Rich (1989), Fisman and Gatti (2002), Fredriksson, List and Millimet (2003) and Glaeser and Saks (2004) to measure corruption across states. The summary statistics for all of these variables are given in Table 3.

\section{Results}

Polarization and Inequality: Direct Effects

Our basic model is as follows:

$$
\begin{aligned}
& \text { Gini }_{\mathrm{s}, \mathrm{t} 1}=\text { Intercept }_{\mathrm{t} 1}+\beta_{1} \text { EPI/RPI }_{\mathrm{s}, \mathrm{t} 1}+\beta_{2} X_{\mathrm{s}, \mathrm{t} 1}+\varepsilon_{\mathrm{s}, \mathrm{t} 1} \\
& \text { Gini }_{\mathrm{s}, \mathrm{t} 2}=\text { Intercept }_{\mathrm{t} 2}+\beta_{1} \text { EPI }_{\mathrm{RPI}} I_{\mathrm{s}, \mathrm{t} 2}+\beta_{2} X_{\mathrm{s}, \mathrm{t} 2}+\varepsilon_{\mathrm{s}, \mathrm{t} 2}
\end{aligned}
$$

where Gini $_{\mathrm{s}, \mathrm{t}}$ represents the Gini coefficient in state s during period t. EPI/RPI $I_{\mathrm{s}, \mathrm{t}}$ represents the ethnic/religious polarization index and $X_{\mathrm{s}, \mathrm{t}}$ represents the set of control variables that affect income inequality (Female Head, Young, Old, College, Minimum Wage, AFDC/TANF, Unemployment Insurance, Unemployment Rate, Union, Corruption, and regional dummy variables South, Midwest, and West). We estimate our model using SUR. SUR is a flexible form of Random Effects (RE) estimation and is widely used in cross country growth regressions since it allows for the error terms to be correlated across periods (Alesina et al. 2004, Alesina and La Ferrara 2005). We first formulate a separate regression for each period, then constrain government is able to improve the distribution of income the more corruption there is. In other words, "the benefits from corruption are likely to accrue to the better connected individuals ... who belong mostly to high income groups" (Gupta et. al. 2002, 23). According to Jonston (1989), corruption favors the 'haves' rather than the 'have nots' particularly if the stakes are large. 
the coefficients to be equal across periods and estimate the resulting system by generalized least squares (GLS). If the error terms are not correlated there is no payoff to GLS estimation-GLS is then simply equation-by-equation ordinary least squares (OLS). The greater the correlation of the error terms, the greater the efficiency gain accruing to GLS (Greene 2003). In our regressions, the correlation coefficient of the error terms across periods is higher than $0.70{ }^{2}$

The results of the SUR estimation for the individual effects of ethnic and religious polarization on income inequality are given in the first two columns of Table 4 . The estimated coefficients of $E P I$ and $R P I$ are both positive and significant at the 1 percent and 10 percent levels respectively, indicating a strong positive relationship between ethnic and religious heterogeneity and income inequality. As the results given in Table 4 suggest, going from complete ethnic (religious) homogeneity (and index of 0 ) to complete ethnic (religious) heterogeneity (an index of 1) increases the Gini coefficient by almost 3 (respectively, 3) percentage points. Up to 2.4 percentage points of the difference in Gini coefficients (almost 25 percent of the difference) between Vermont and Mississippi is explained by the different degrees of ethnic polarization in those states, and up to 1.3 percentage points of the difference in Gini coefficients (almost 20 percent of the difference) between Utah and Louisiana is explained by different degrees of religious polarization. The third column of Table 4 gives the results of the SUR estimation when EPI and RPI are used together. Again the estimated coefficient of EPI is positive and significant at the 5 percent level. The estimated coefficient of $R P I$ is positive and almost significant at the 10 percent level. The magnitude of the estimated coefficients slightly decreases when we use EPI and RPI together. The estimated coefficient of $E P I$ decreases from 0.029 to 0.026 and that of RPI from 0.029 to 0.018 .

\footnotetext{
${ }^{2}$ The results of RE estimation are very similar to those of the SUR estimations reported here.
} 


\section{Fractionalization and Inequality: Direct Effects}

As mentioned earlier, FI increases with the number of groups. On the other hand, according to Montalvo and Reynal-Querol (2005), ethnic and religious fractionalization do not necessarily increase social conflict: we are, in fact less likely to observe social conflict in highly homogeneous and highly heterogeneous countries; increases in heterogeneity, after some point, decrease the effect of an individual ethnic or religious group on redistribution. If this is indeed the case, we should see an inverse-U shaped relationship between the fractionalization indices and the Gini coefficient and there should be an inequality maximizing level of fractionalization. To capture the presence of such a relationship we modify our basic model as follows:

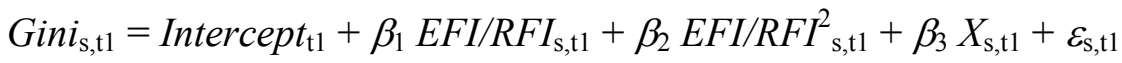

$$
\begin{aligned}
& \text { Gini }_{\mathrm{s}, \mathrm{t} 2}=\text { Intercept }_{\mathrm{t} 2}+\beta_{1} E F I / R F I_{\mathrm{s}, \mathrm{t} 1}+\beta_{2} E F I / R F I_{\mathrm{s}, \mathrm{t} 2}^{2}+\beta_{3} X_{\mathrm{s}, \mathrm{t} 2}+\varepsilon_{\mathrm{s}, \mathrm{t} 2} .
\end{aligned}
$$

The results of the SUR estimation for the individual effects of ethnic and religious fractionalization on income inequality are given in the first two columns of Table 5. The estimated coefficients of $E F I$ and $R F I$ are positive and significant at the 1 percent and 10 percent levels respectively, and the estimated coefficients of $E F I^{2}$ and $R F I^{2}$ are negative and both are significant at the 5 percent level. This does indeed indicate an inverse-U shaped relationship between the fractionalization indices and the Gini coefficient. All else constant, the Gini coefficient is maximized when $E F I=0.62$ and when $R F I=0.54$ which fall well within the range of observed values of EFI $(0.03 ; 0.90)$ and RFI $(0.18 ; 0.87)$. The third column of Table 5 gives the results of the SUR estimation when ethnic and religious fractionalization indices are used together. The estimated coefficients of EFI and RFI continue to be positive and the estimated coefficient of $E F I$ is significant at 1 percent level. The estimated coefficients of $E F I^{2}$ and $R F I^{2}$ continue to be negative and the estimated coefficient of $E F I^{2}$ is significant at 5 percent 
level. The magnitude of the estimated coefficients changes slightly. When we use ethnic and religious fractionalization indices together, the estimated coefficient of $E F I$ increases from 0.095 to 0.096 and that of $R F I$ decreases from 0.108 to 0.081 . The estimated coefficient of $E F I^{2}$ decreases from -0.077 to -0.088 and that of $R F I^{2}$ increases from -0.100 to $-0.080 .^{3}$

Our results about the effects of macroeconomic and demographic variables on income inequality are mostly consistent with the earlier studies. The estimated coefficients of Unemployment Rate, GSP Growth, Female Head, Old, and Corruption are significant in almost all estimations. We find that increases in Unemployment Rate increase the Gini coefficient. The higher the percentage of female headed families, and the higher the percentage of the population over 65, the higher is the income inequality (Wu, Perloff, and Golan 2005). GSP Growth has an equalizing effect while Corruption tends to increase the income inequality (Li et al. 2000, and Gupta et al. 2002). Among the government policy variables, only the coefficient of $A F D C / T A N F$ is significant. We find that $A F D C / T A N F$ payments decrease the Gini coefficient. $^{4}$

Fractionalization, Polarization, and Inequality: Indirect Effects

One of the reasons why ethnic and religious heterogeneity affect income distribution is that they affect the channels of redistribution such as welfare programs. Using data on AFDC/TANF payments for 50 US states, Alesina and Glaeser (2004) find a negative relationship between the percentage of the black population in a state and the level of AFDC/TANF payments, and they conclude that ethnically heterogeneous states of the south in

\footnotetext{
${ }^{3}$ We do not report the estimated coefficients of $E P I^{2}$ and $R P I^{2}$ since they are not statistically significant in any specification.

${ }^{4} \mathrm{Wu}$, Perloff, and Golan (2005) do not find a significant relationship between the AFDC/TANF payments and income inequality.
} 
US are much less generous than their more homogeneous counterparts. As Alesina and Glaeser (2004) argue, the $A F D C / T A N F$ is perhaps the largest welfare scheme in US. In our regressions we find a negative relationship between the $A F D C / T A N F$ payments and the Gini coefficient which is significant at the 5 percent, sometimes 1 percent level, indicating that the program is in fact a successful redistribution channel. It now becomes natural to ask if the fractionalization and the polarization affect the $A F D C / T A N F$ payments as they affect the Gini coefficient. The results of the SUR estimation are given in Table 6 and Table7.

Regarding polarization, the estimated coefficients of $E P I$ and $R P I$ are negative and significant at the 1 percent and 10 percent levels respectively, although the estimated coefficient of $R P I$ loses its significance when we use EPI and RPI together. Alesina and Glaeser (2004) find that if the percentage of the black population in a state rises from 0 to 20 percent, the monthly AFDC/TANF payment declines by $\$ 151$. We find that going from complete ethnic homogeneity to complete ethnic heterogeneity causes the monthly $A F D C / T A N F$ payment to decrease by $\$ 196$ and going from complete religious homogeneity to complete religious heterogeneity causes it to decrease by $\$ 208$. Up to $\$ 165$ of the difference in monthly AFDC/TANF payment (almost 35 percent of the difference) between Vermont and Mississippi is explained by the different degrees of ethnic polarization in those states, and up to $\$ 95$ of the difference in monthly AFDC/TANF payment (almost 50 percent of the difference) between Utah and Louisiana is explained by different degrees of religious polarization. As for fractionalization, the estimated coefficients of $E F I$ and $R F I$ are negative and significant at the 1 percent and 10 percent levels respectively; and the estimated coefficients of $E F I^{2}$ and $R F I^{2}$ are positive an significant at 1 percent and 10 percent levels respectively, although the coefficients of $R F I$ and $R F I^{2}$ lose their significance when we use both ethnic and religious fractionalization indices at the same time. In other words, we find U-shaped relationships of ethnic and religious 
fractionalization with $A F D C / T A N F$ payments. As the results given in Table 7 indicate, monthly $A F D C / T A N F$ payment is minimized when $E F I=0.50$ and it is minimized when $R F I=0.63$ which again fall in the middle-part of the range of observed values of EFI $(0.03 ; 0.90)$ and RFI $(0.18$; 0.87). ${ }^{5}$ Figure 10 and Figure 11 show the negative relationships between the polarization indices and the $A F D C / T A N F$ payments. The U-shaped relationships between the fractionalization indices and the $A F D C / T A N F$ payments are shown in Figure 12 and Figure 13.

The only control variable Alesina and Glaeser (2004) use is the annual median income in each state. They find that if annual state median income rises by $\$ 100$, monthly payment rises by almost $\$ 1.50$ per month. Our results are very close to theirs. We find that if annual state income rises by $\$ 100$, monthly payment rises by almost $\$ 1$.

\section{Conclusion}

The root causes of income inequality continue to be among the most challenging questions in economics literature. In this study we analyze the direct and indirect effects of ethnic and religious heterogeneity on income inequality. When we use the polarization index as our measure of heterogeneity, we find a positive and linear relationship between ethnic and religious heterogeneity and the Gini coefficient and a negative and linear relationship between ethnic and religious heterogeneity and $A F D C / T A N F$ payments. When we use the fractionalization index as our measure of heterogeneity we find an inverse-U shaped relationship between ethnic and religious heterogeneity and the Gini coefficient, and a Ushaped relationship between ethnic and religious heterogeneity and AFDC/TANF payments.

\footnotetext{
${ }^{5}$ While the estimated coefficients of $E P I^{2}$ are statistically significant at the 1 percent level in all specifications, the estimated coefficients of $R P I^{2}$ are not significant at all.
} 
According to our estimations, ethnic and religious polarization explain almost $37 \%$ of the variation in the Gini coefficients across states (close to $75 \%$ when control variables are included) and almost $10 \%$ of the variation in $A F D C / T A N F$ payments (close to $65 \%$ when control variables are included). Similarly, fractionalization explains almost $40 \%$ of the variation in Gini coefficients (close to $80 \%$ when control variables are included) and almost $20 \%$ of the variation in AFDC/TANF payments (close to $65 \%$ when control variables are included).

The role of ethnic and religious groups within the distribution process increased significantly in the last decade. According to the National Congregations Study, 57 percent of congregations engage in redistributive activities. 11 percent have clothing projects, 18 percent have housing/shelter projects, and 33 percent have food-related projects. Of the congregations engaged in some level of activity, 90 percent support at least one activity with volunteers. The median amount spent by congregations directly in support of redistributive activities is $\$ 1200$ representing about 3 percent of a congregation's total budget. The engagement of the religious groups is likely to increase further as several states establish programs that encourage religious groups to apply for funding. California, for example, recently launched a faith-based initiative that dedicated up to $\$ 5$ million in grants to religious groups for employment assistance programs (Chaves 2001). As Chaves (2001) argues, there is much to say about these efforts. "They raise legal, moral, theological, and sociological questions, all of which deserve close attention" (Chaves 2001, 122). This study clearly adds economic perspectives and questions to the other ones.

There are, of course many questions thrown up by our analysis and a number of pathways are opened for future research. It necessarily has shortcomings, not least those which are induced by data deficiencies. Nevertheless, the already conclusive nature of our early results indicates that deeper analysis of this issue is worthwhile. Provided that the data are available, it 
will definitely be interesting for example to analyze the effects of heterogeneity on withingroup inequality as well as between-group inequality. 


\section{References}

Alesina, A., A. Devleeschauwer, W. Easterly, S. Kurlat, R. Wacziarg (2003).

"Fractionalization." Journal of Economic Growth 8: 155-194.

Alesina, A. and E. L. Glaeser (2004). Fighting Poverty in US and Europe. Oxford: Oxford University Press.

Alesina, A., E. La Ferrara (2005). "Ethnic Diversity and Economic Performance.” Journal of Economic Literature 43: 762-800.

Bobo, L. and J. R. Kluegel (1993). “Opposition to Race Targeting: Self Interest, Stratification Ideology, or Racial Attitudes.” American Sociological Review 58: 443-464.

Bobo, L. and V. L. Hutchings (1996). "Perceptions of Racial Group Competition: Extending Blumer's Theory of Group Position to a Multiracial Social Context." American Sociological Review 61: 951-972.

Chaves, M (2001). "Religious Congregations and Welfare Reform: Assessing the Potential." 121-139 in Can Charitable Choice Work? Covering Religion's Impact on Urban Affairs and Social Services edited by Andrew Walsh, Hartford, CT: The Leonard E. Greenberg Center for the Study of Religion in Public Life.

Fisman, R. and R. Gatti (2002). "Decentralization and Corruption: Evidence from US Federal Transfer Programs." Public Choice 113: 25-35.

Fredriksson, P. G., J. A. List and D. L. Millimet (2003). "Bureaucratic Corruption, Environmental Policy and Inbound US FDI: Theory and Evidence. Journal of Public Economics 87: 1407-1430

Glaeser, E. L. (2005). “Inequality.” HIER Discussion Paper 2078.

Glaeser, E. L. and R. E. Saks (2004). Corruption in America. NBER Working Paper 10821.

Goel, R. and D. Rich (1989). “On the Economic Incentives for Taking Bribes.” Public Choice 61: 269-275. 
Greene, W. H. (2003). Econometric Analysis. New York: Prentice Hall.

Gupta, S., H. Davoodi, and R. Alonso-Terme (2002). "Does Corruption Affect Income inequality and Poverty?" Economics of Governance 3: 23-45.

Hirsch, B. T., D. A. Macpherson, D. A. and W. G. Vroman, (2001) "Estimates of Union Density by State." Monthly Labor Review 124: 51-55.

Johnston, M. (1989). Corruption, Inequality, and Change. In P. M. Ward (Eds.), Corruption, Development and Inequality, 13-37, London: Routledge.

Li, H., L. C. Xu, and H. F. Zou (2000). "Corruption, Income Distribution, and Growth.” Economics and Politics 12: 155-182.

Luttmer, E. F. P. (2001). “Group Loyalty and the Taste for Redistribution.” Journal of Political Economy 109: 500-528.

Montalvo, J. G. and M. Reynal-Querol (2005). "Ethnic Diversity and Economic Development." Journal of Development Economics 76: 293-323.

Neumark, D. and O. Nizalova (2004). "Minimum Wage Effects in the Longer Run.” NBER Working Paper 10656.

Okten, C. and U. O. Osili (2004). "Contributions in Heterogeneous Communities: Evidence from Indonesia.” Journal of Population Economics 17: 603-626.

Reynal-Querol, M. and Montalvo, J.G. (2000). “A Theory Religious Conflict and Its Effect on Growth.” IVIE Working Paper 2000-04.

Wu, X., J. M. Perloff, and A. Golan (2005). "Effects of Government Policies on Income Distribution and Welfare." Mimeo.

Tanzi, V. (1995). Corruption: Arm's Length Relationships and Markets. In G. Fiorentini and S. Peltzman (Eds.), The Economics of Organized Crime, Cambridge: Cambridge University Press. 


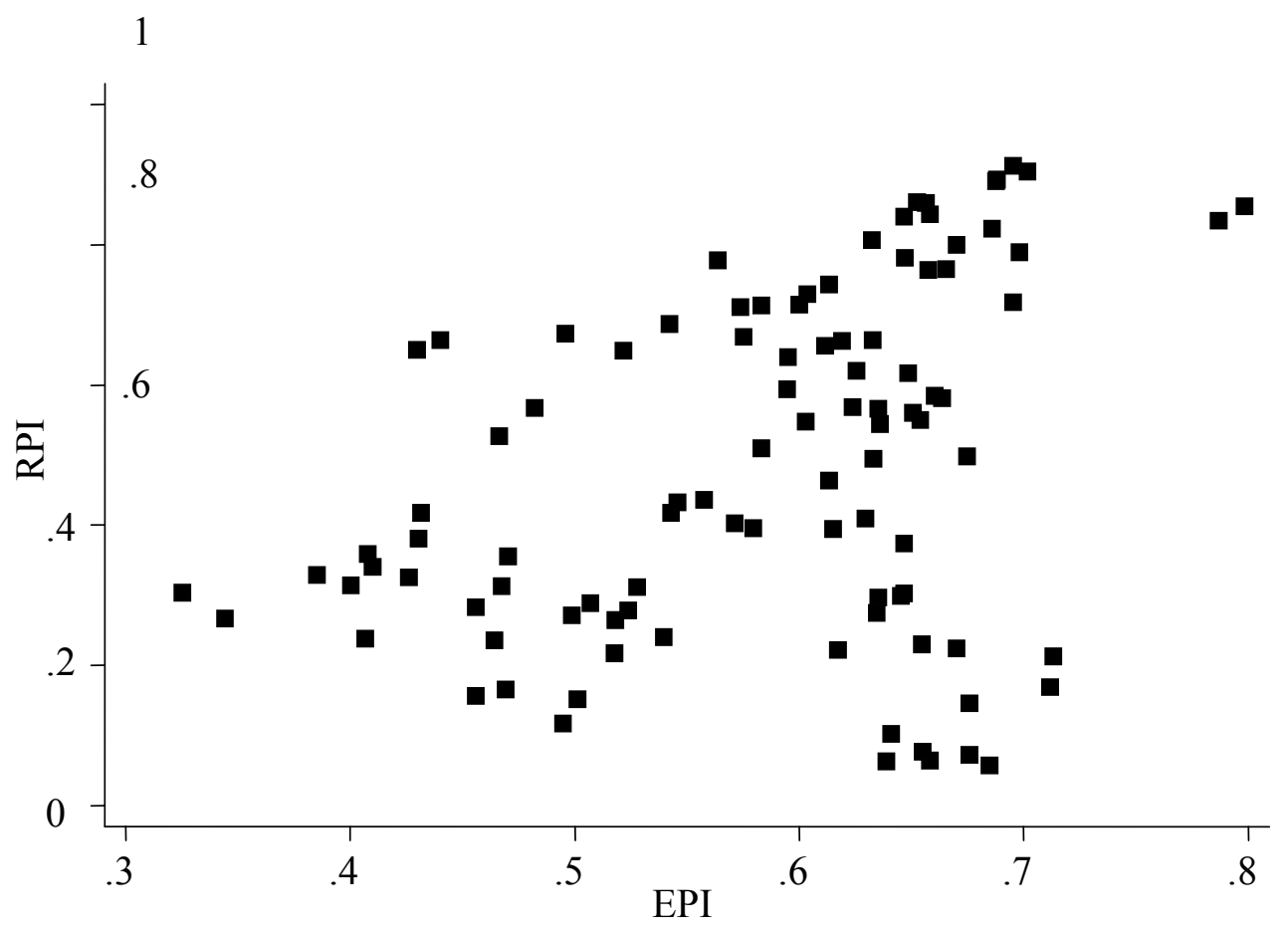

Figure 1. Religious and ethnic polarization

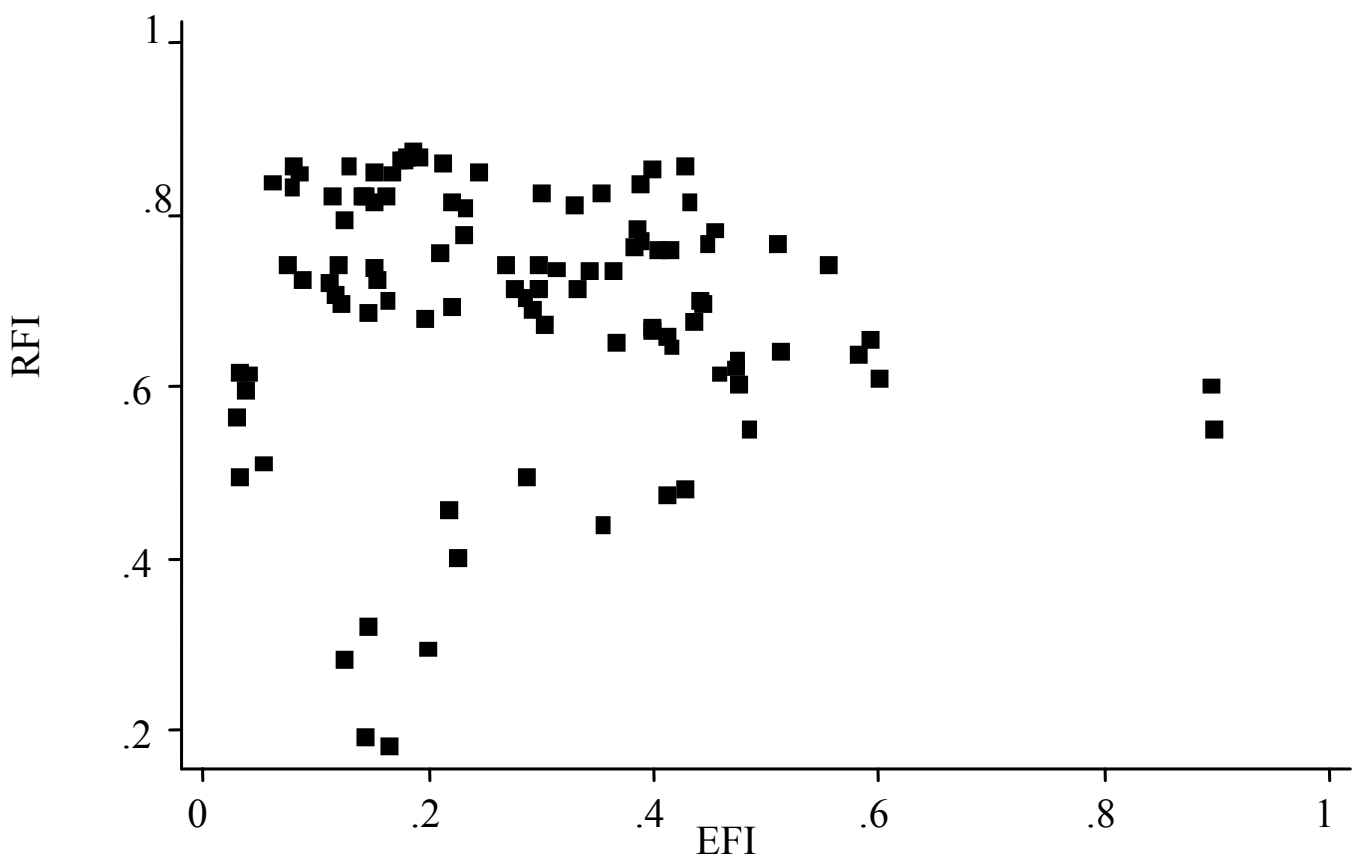

Figure 2. Religious and ethnic fractionalization 


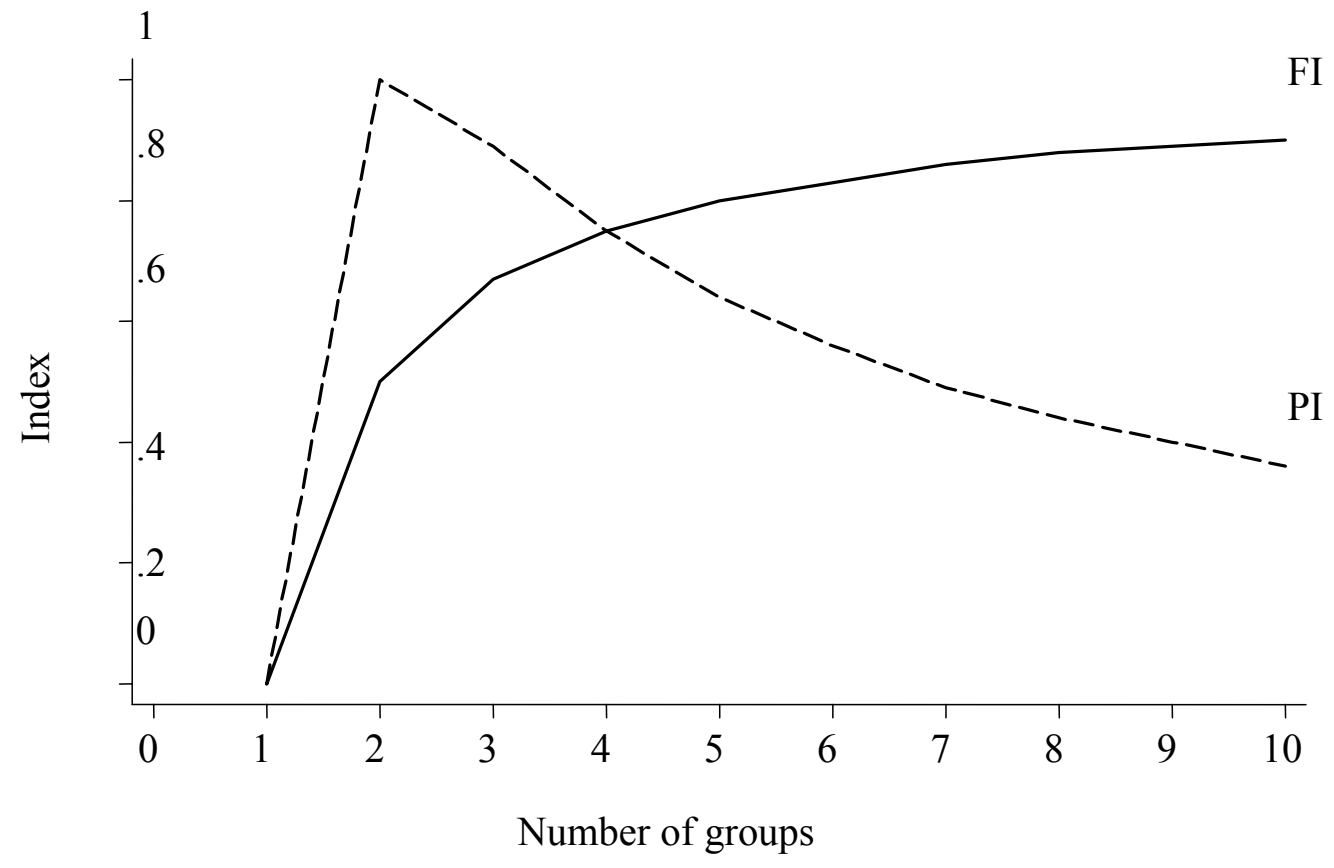

Figure 3. Polarization and fractionalization 


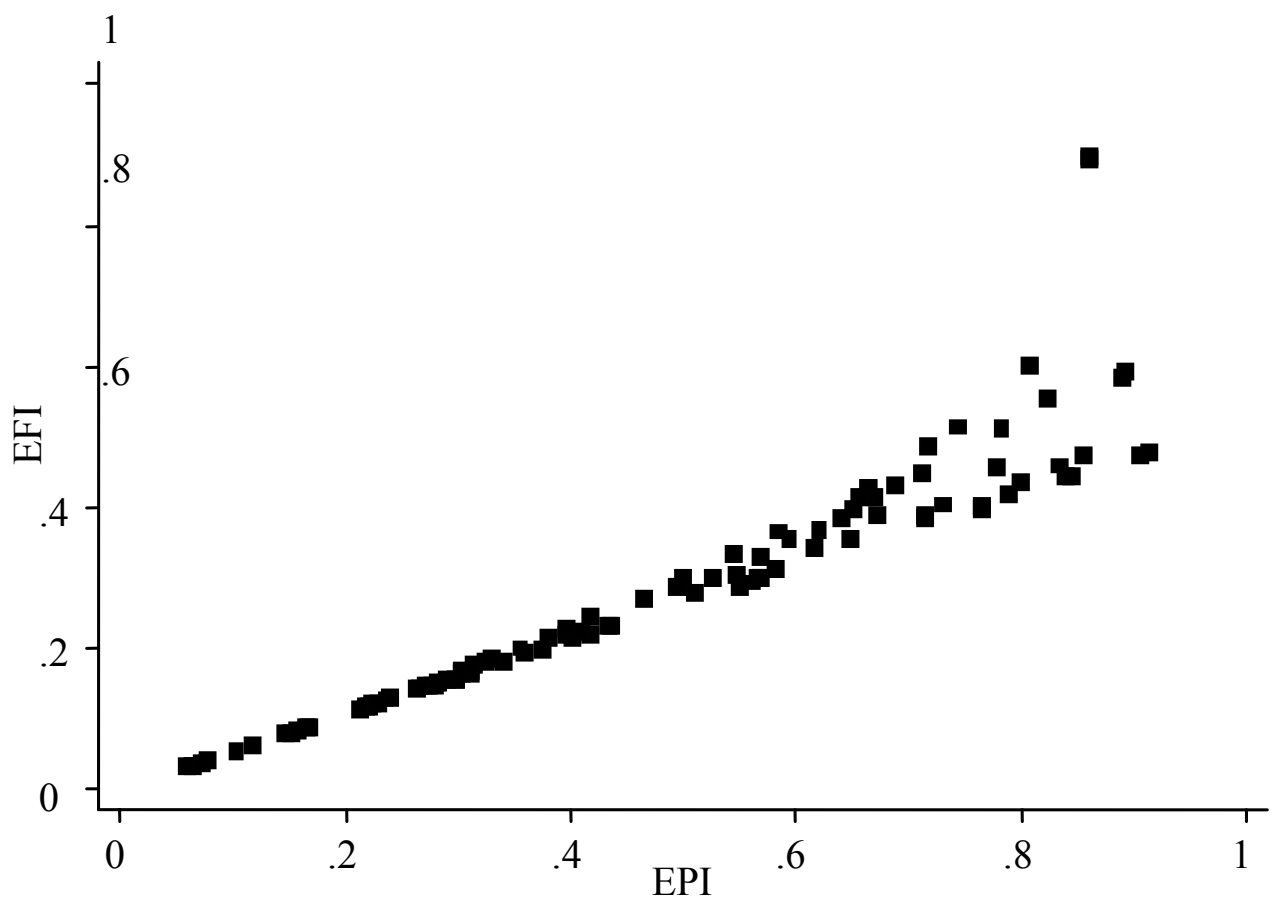

Figure 4. Ethnic fractionalization and polarization 


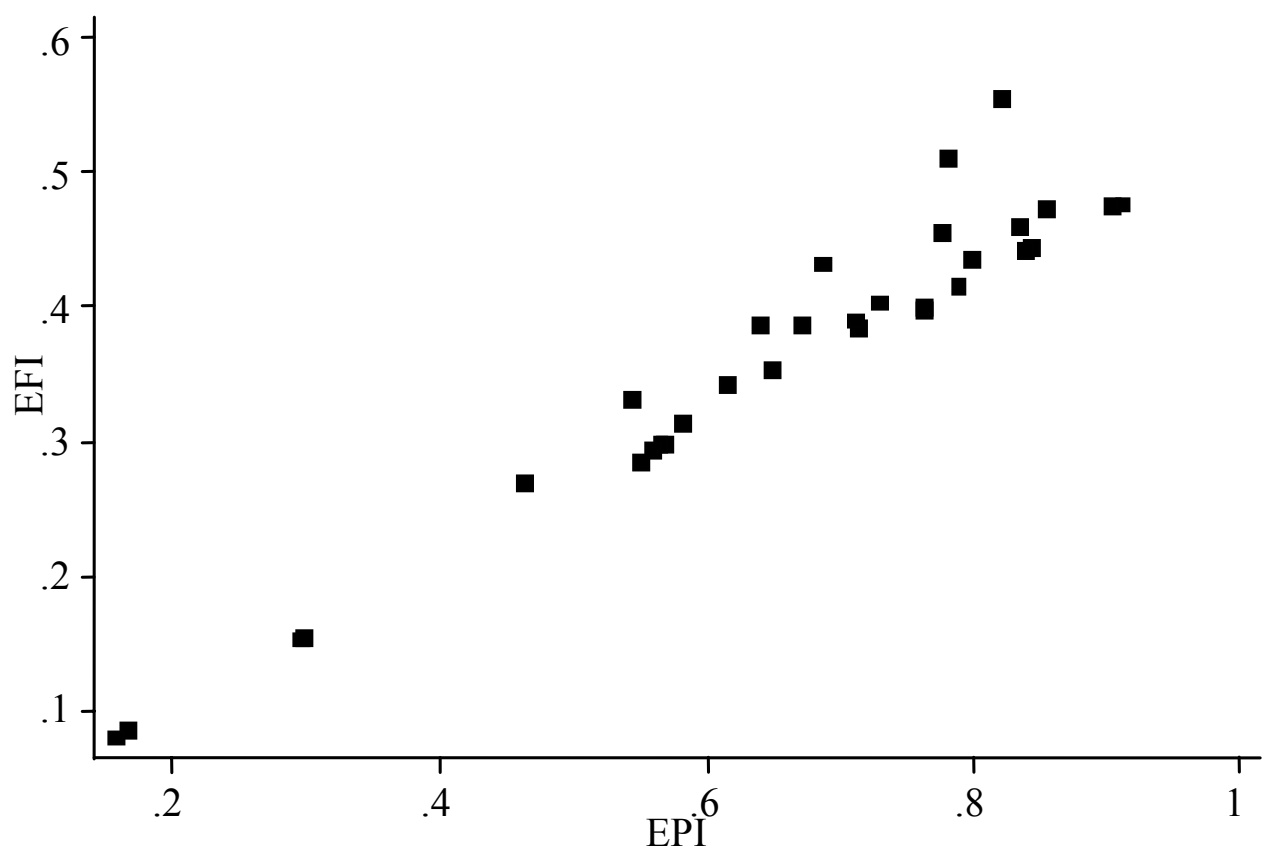

Figure 4a. Ethnic fractionalization and polarization: South

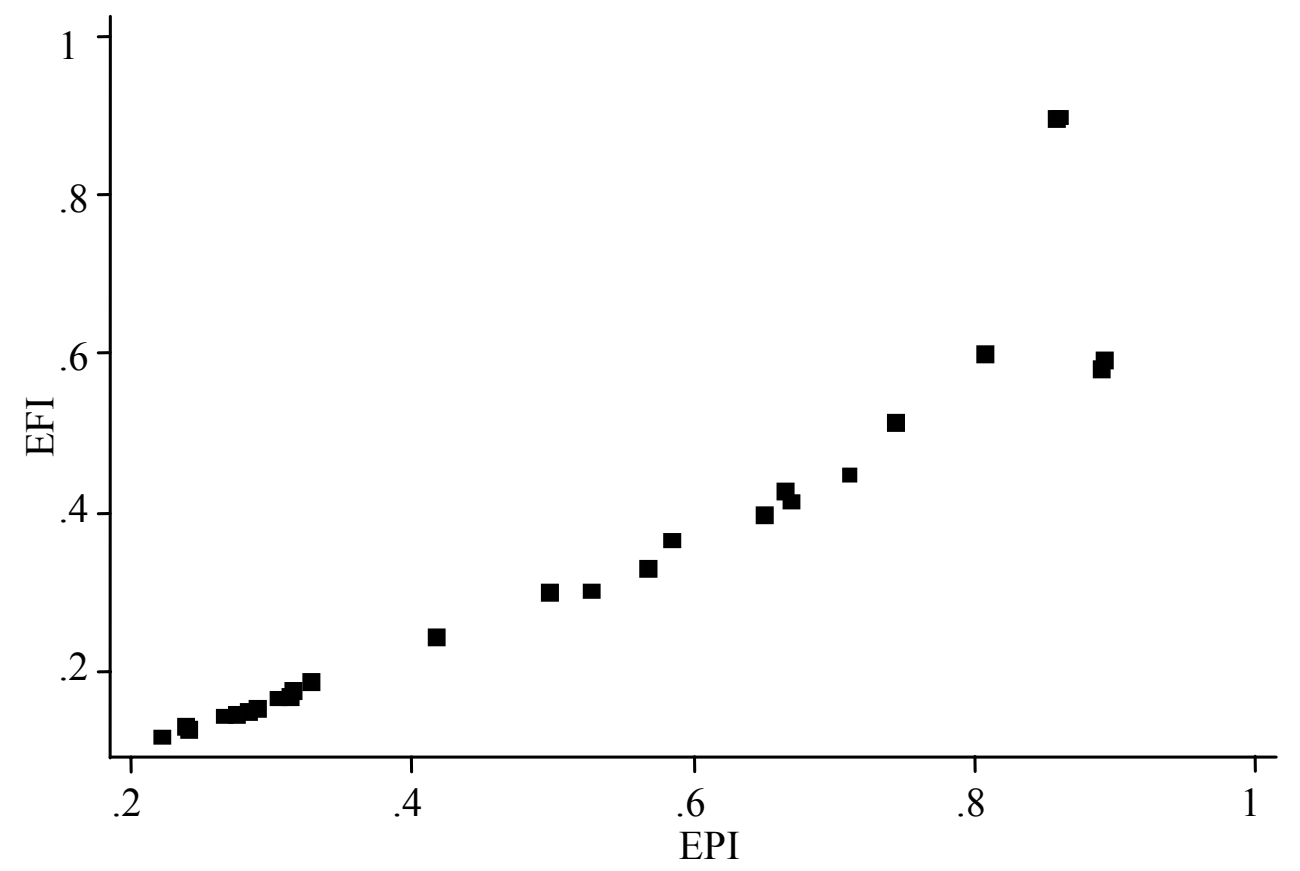

Figure 4b. Ethnic fractionalization and polarization: West 


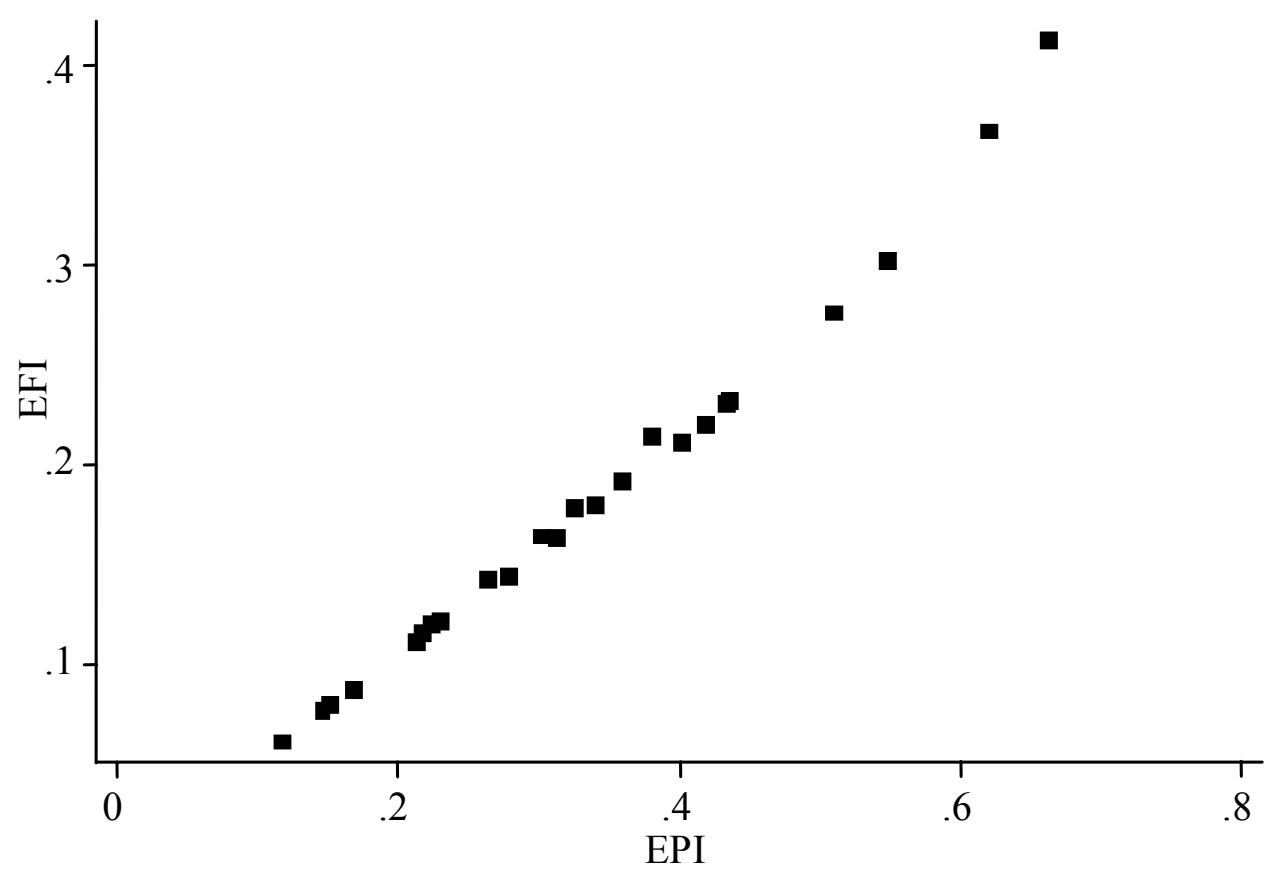

Figure 4c.Ethnic fractionalization and polarization: Midwest

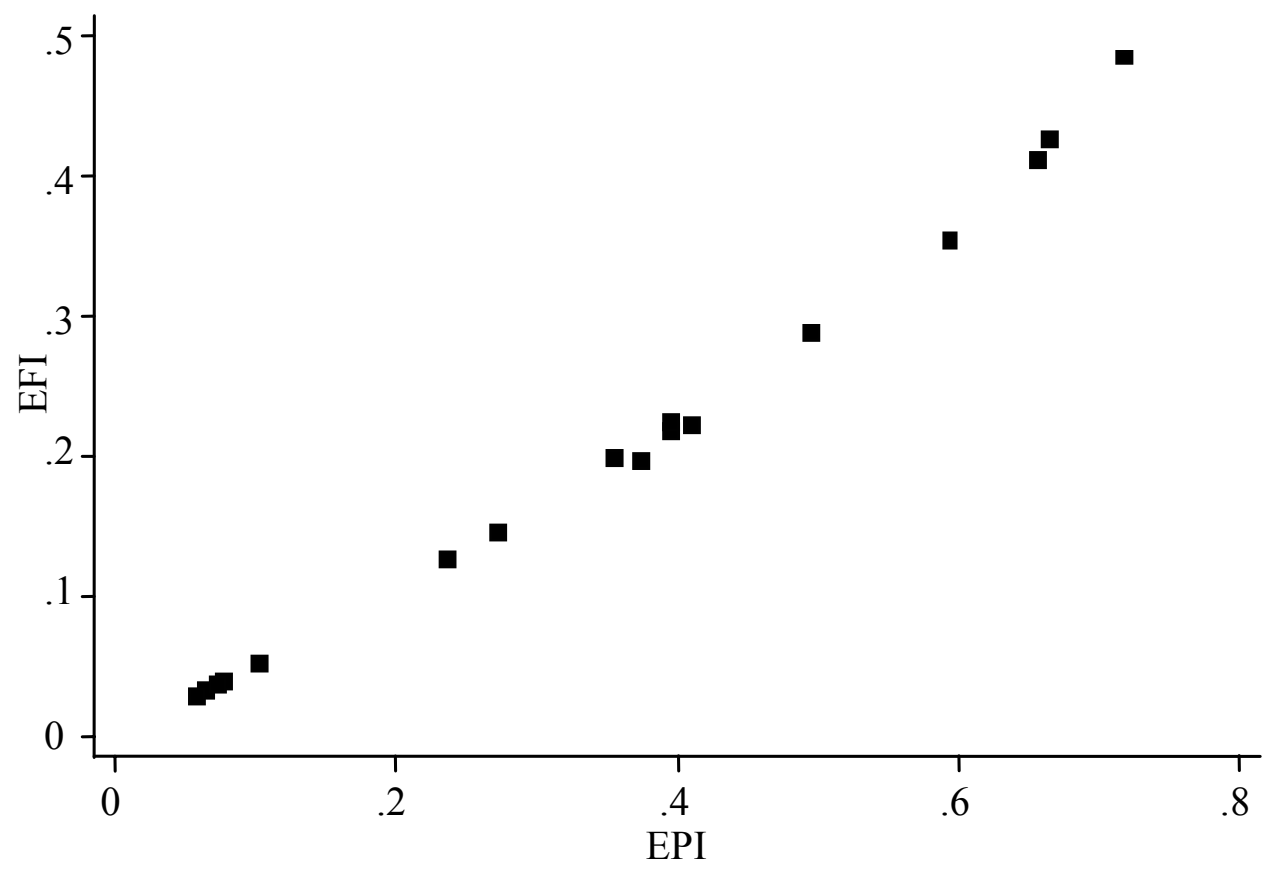

Figure 4d. Ethnic fractionalization and polarization: Northeast 


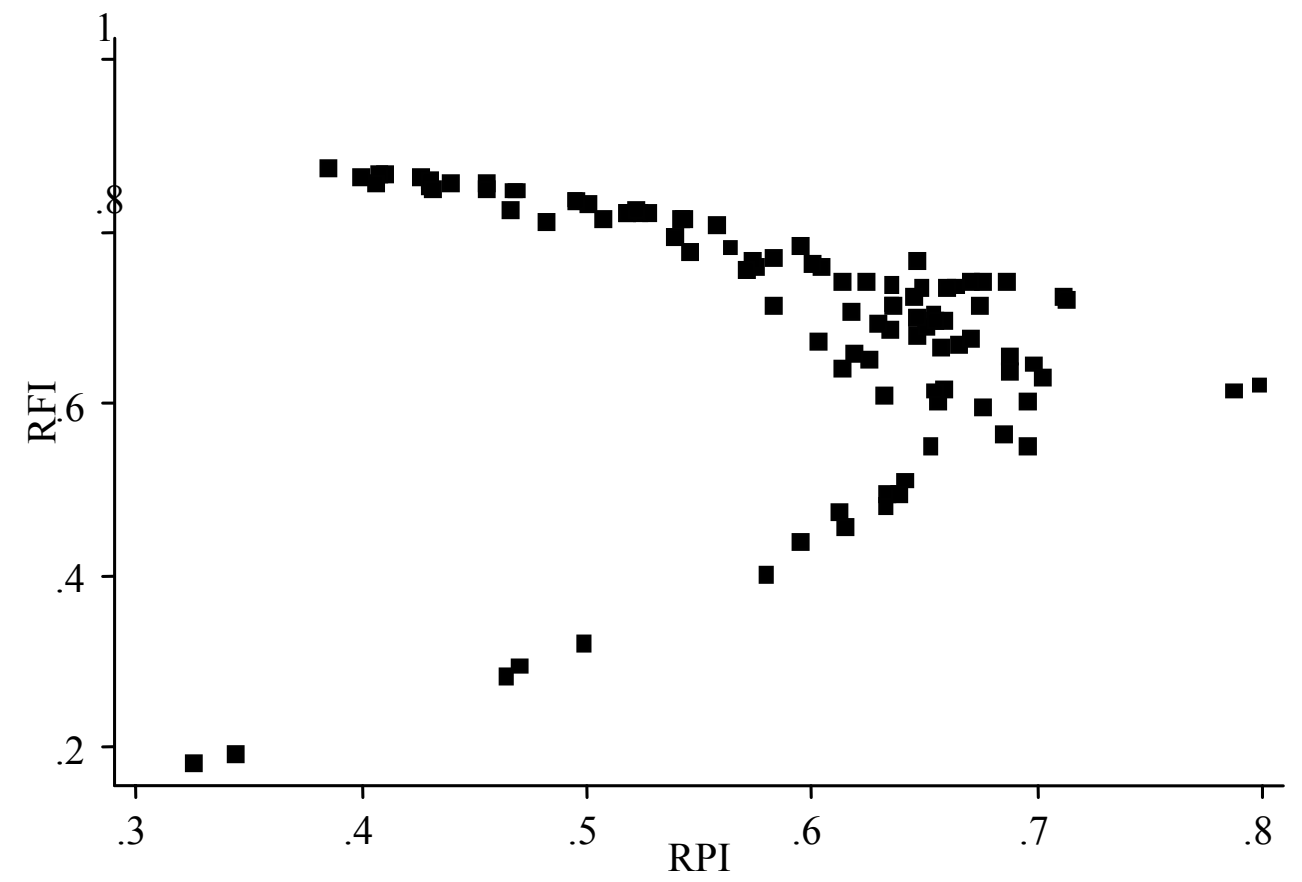

Figure 5. Religious fractionalization and polarization 


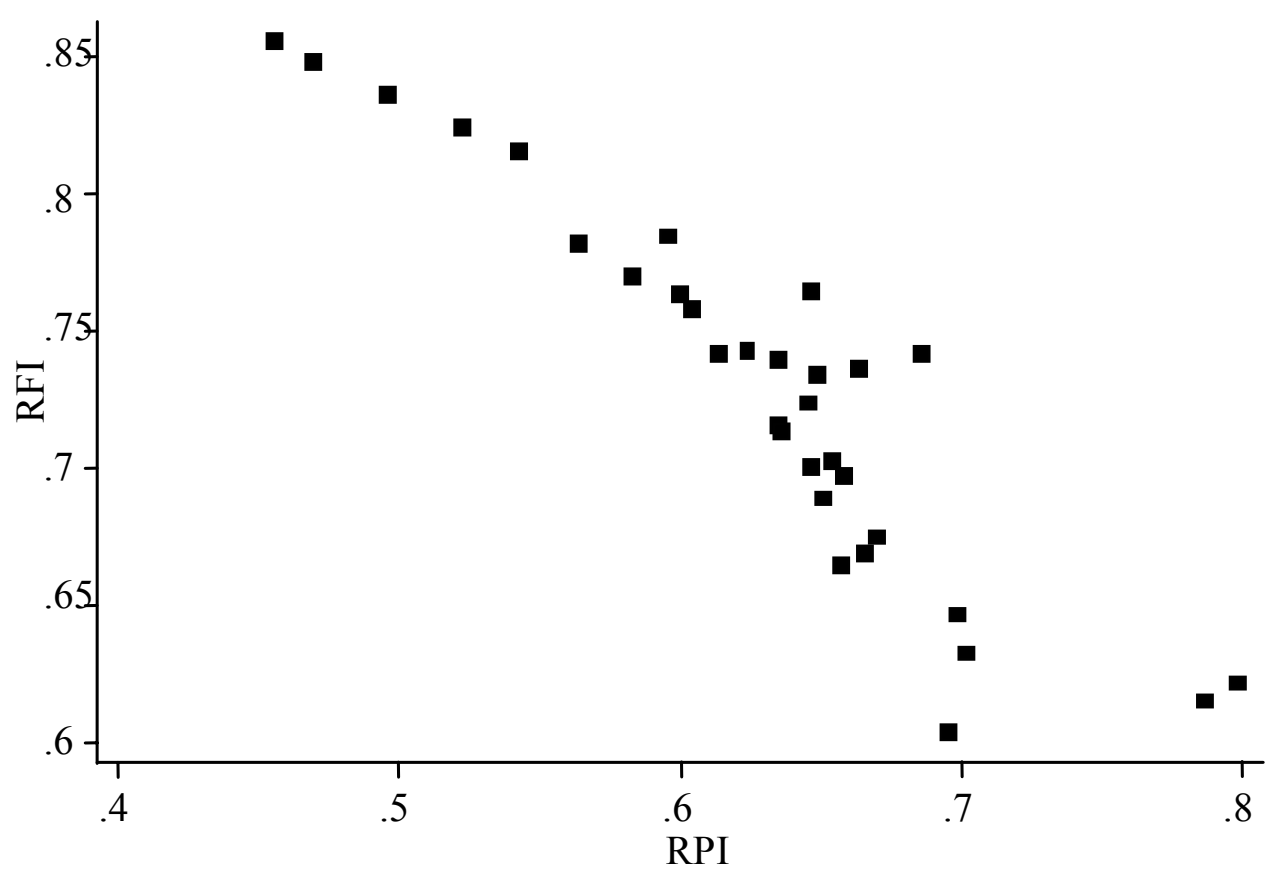

Figure 5a. Religious fractionalization and polarization: South

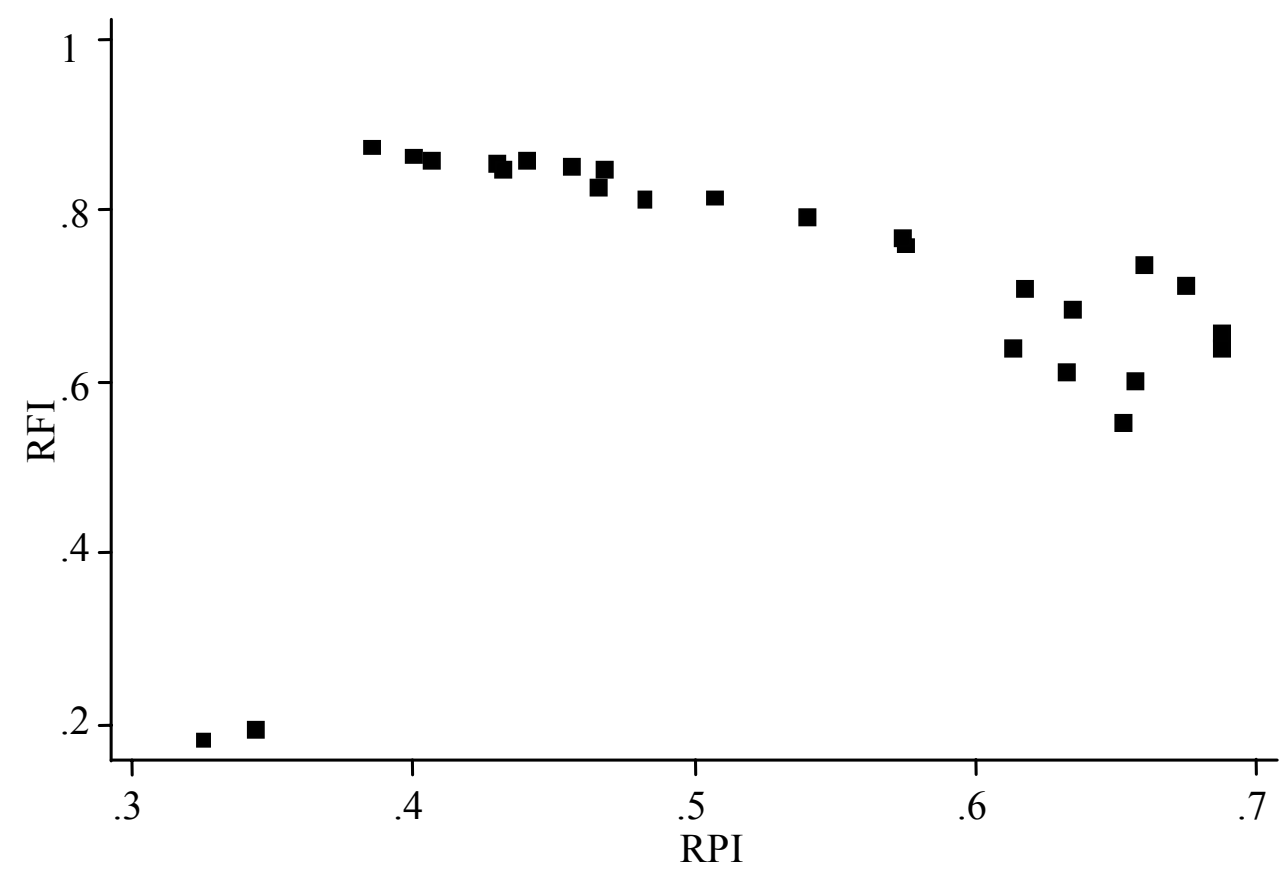

Figure 5b. Religious fractionalization and polarization: West 


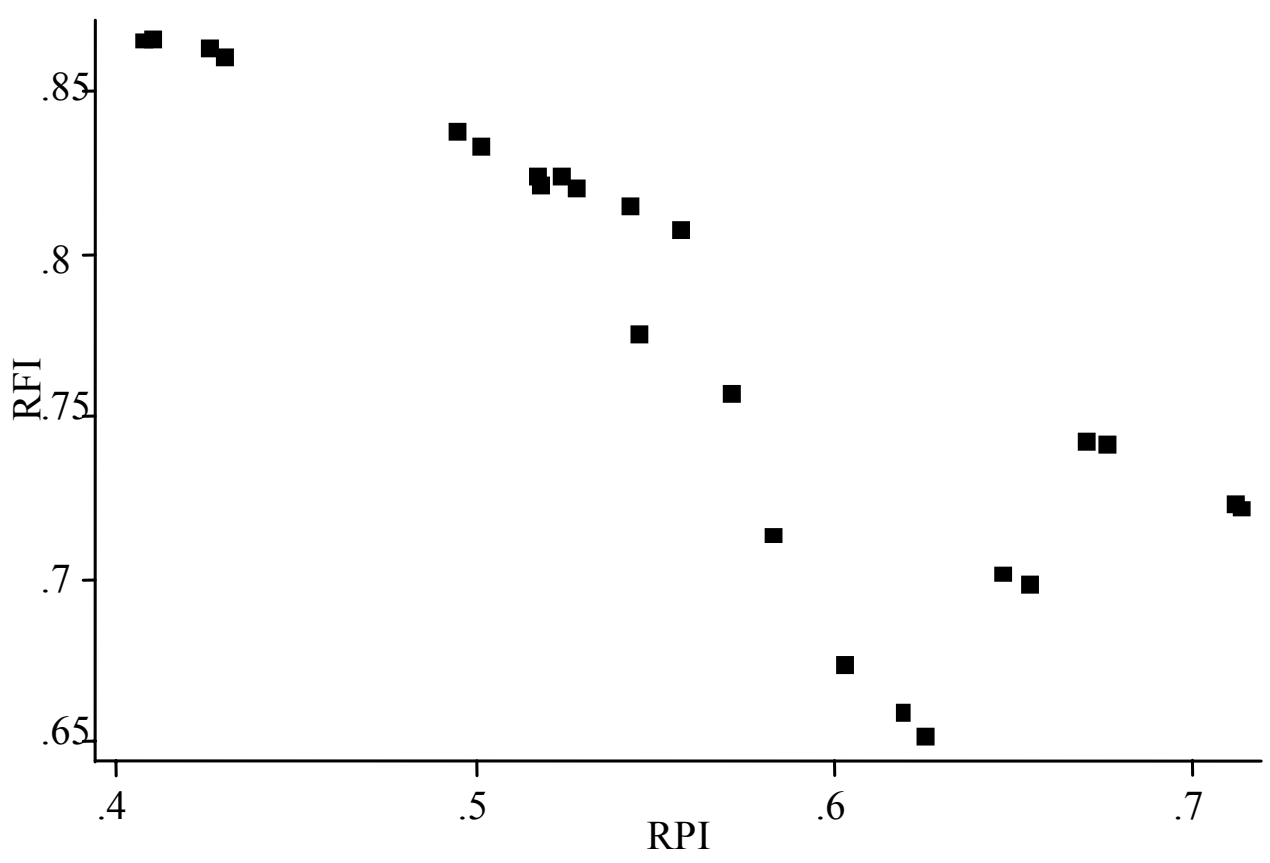

Figure 5c. Religious fractionalization and polarization: Midwest

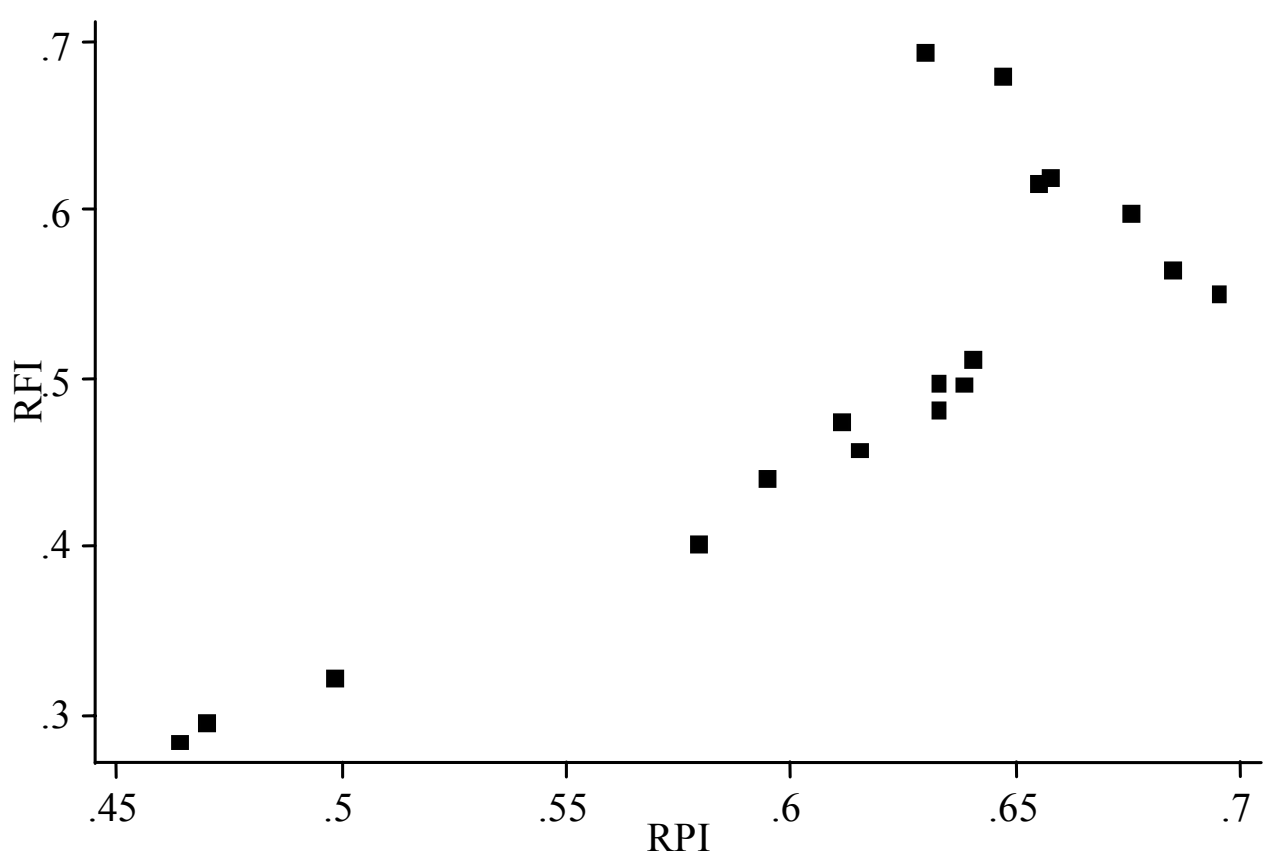

Figure 5d. Religious fractionalization and polarization: Northeast 


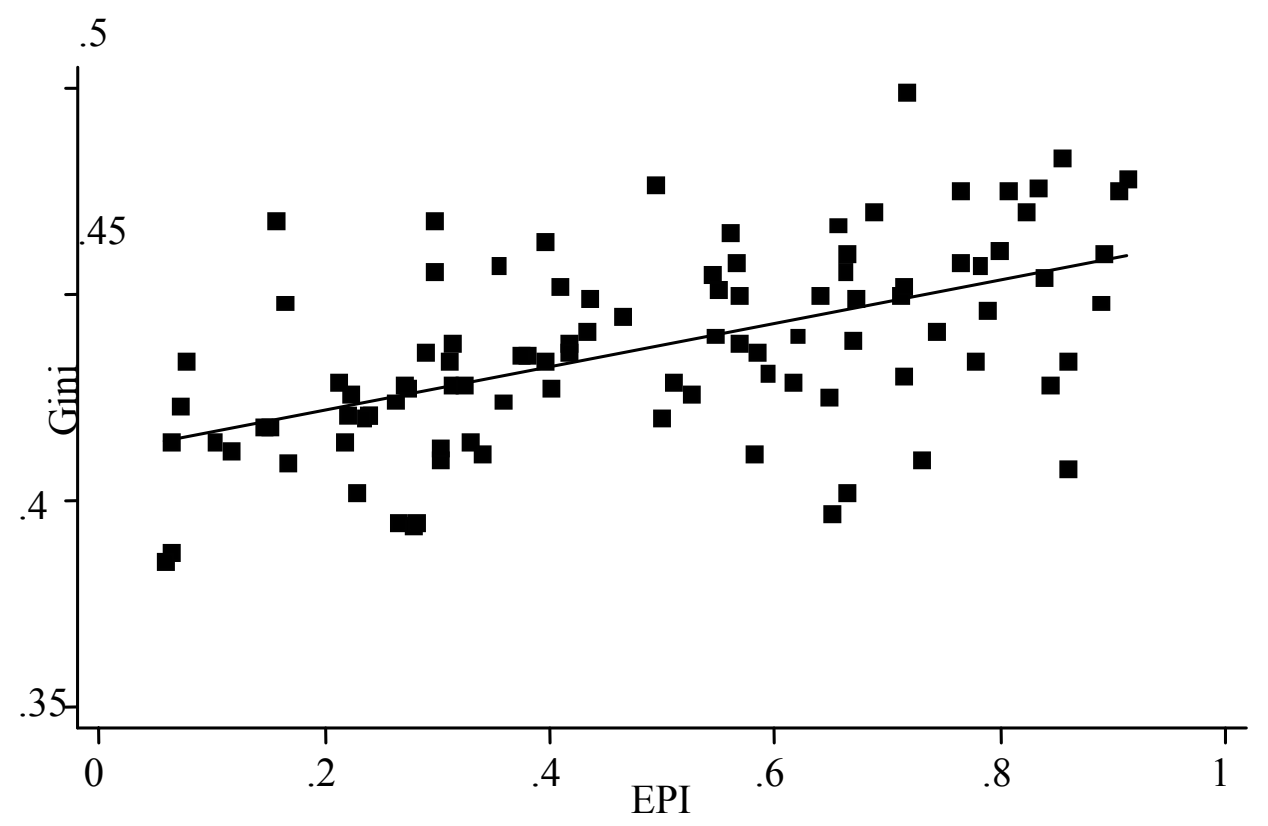

Figure 6. Ethnic polarization and income inequality

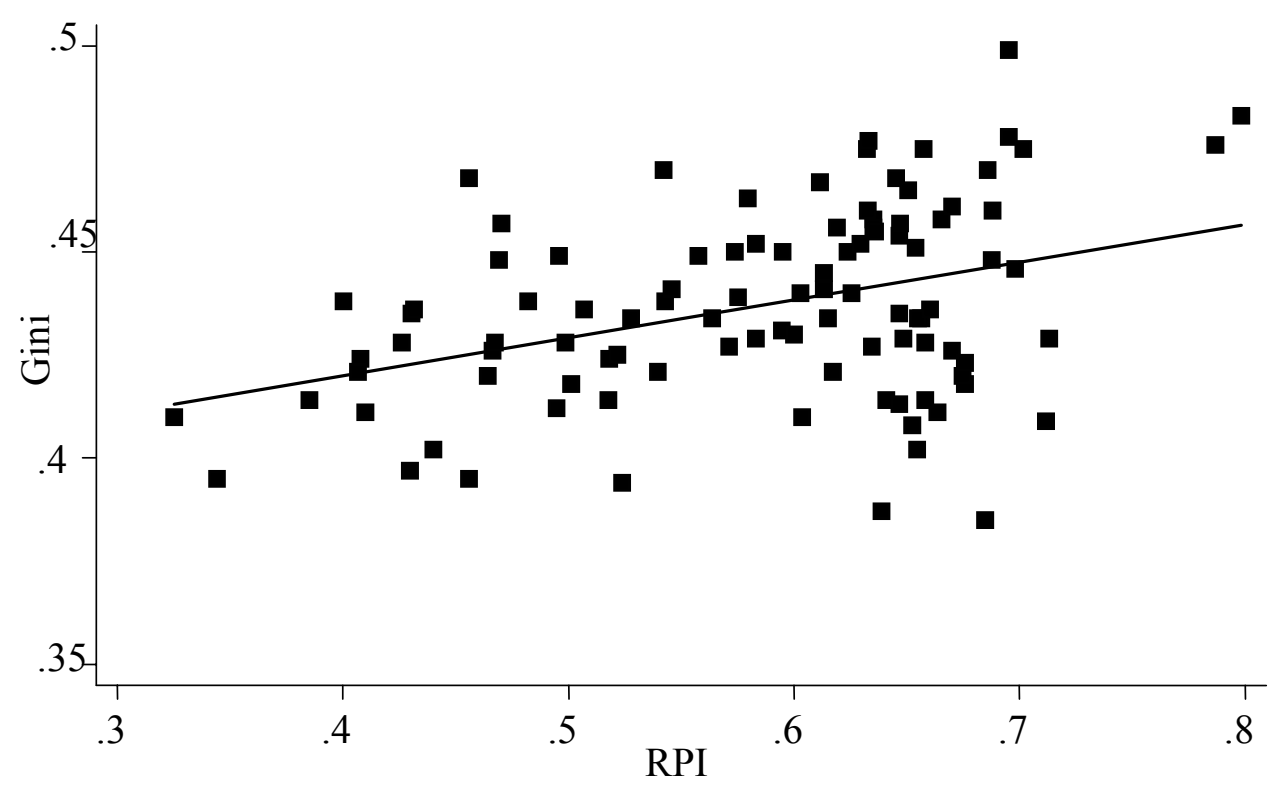

Figure 7. Religious polarization and income inequality 


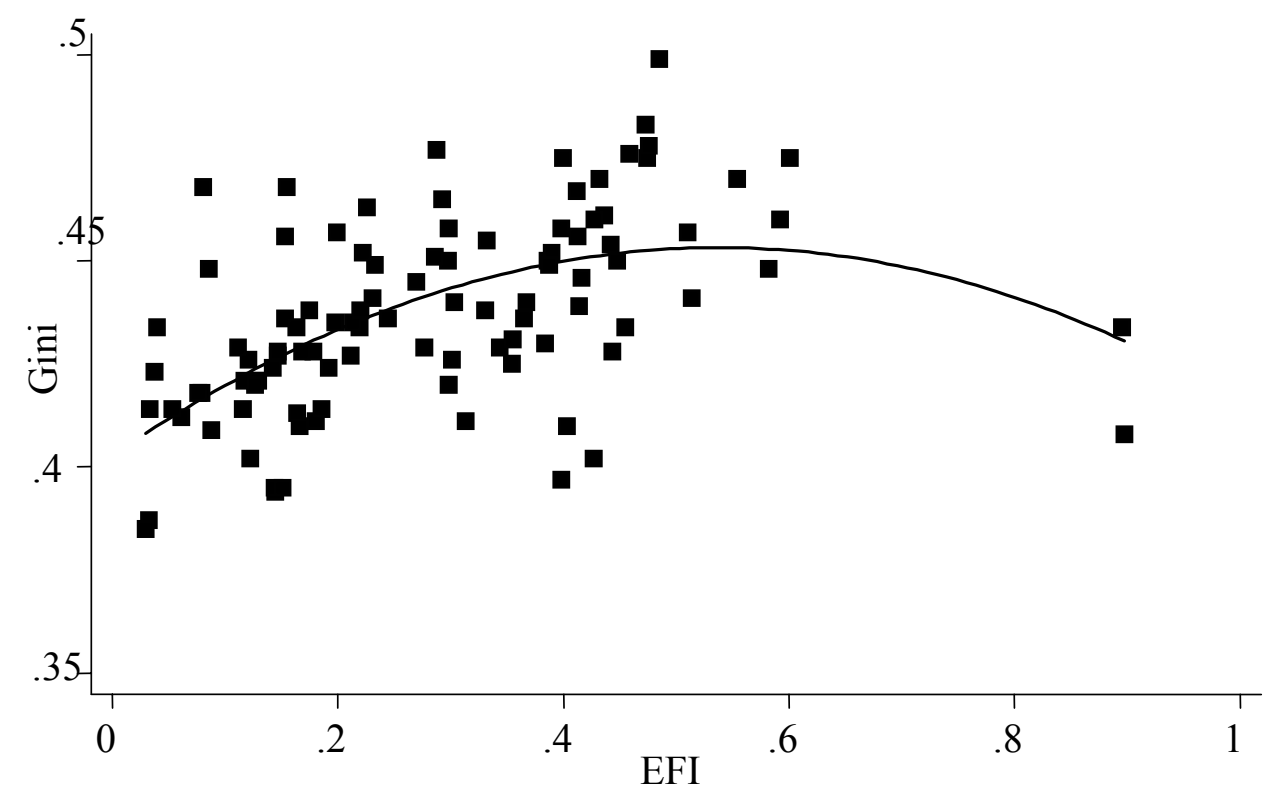

Figure 8. Ethnic fractionalization and income inequality

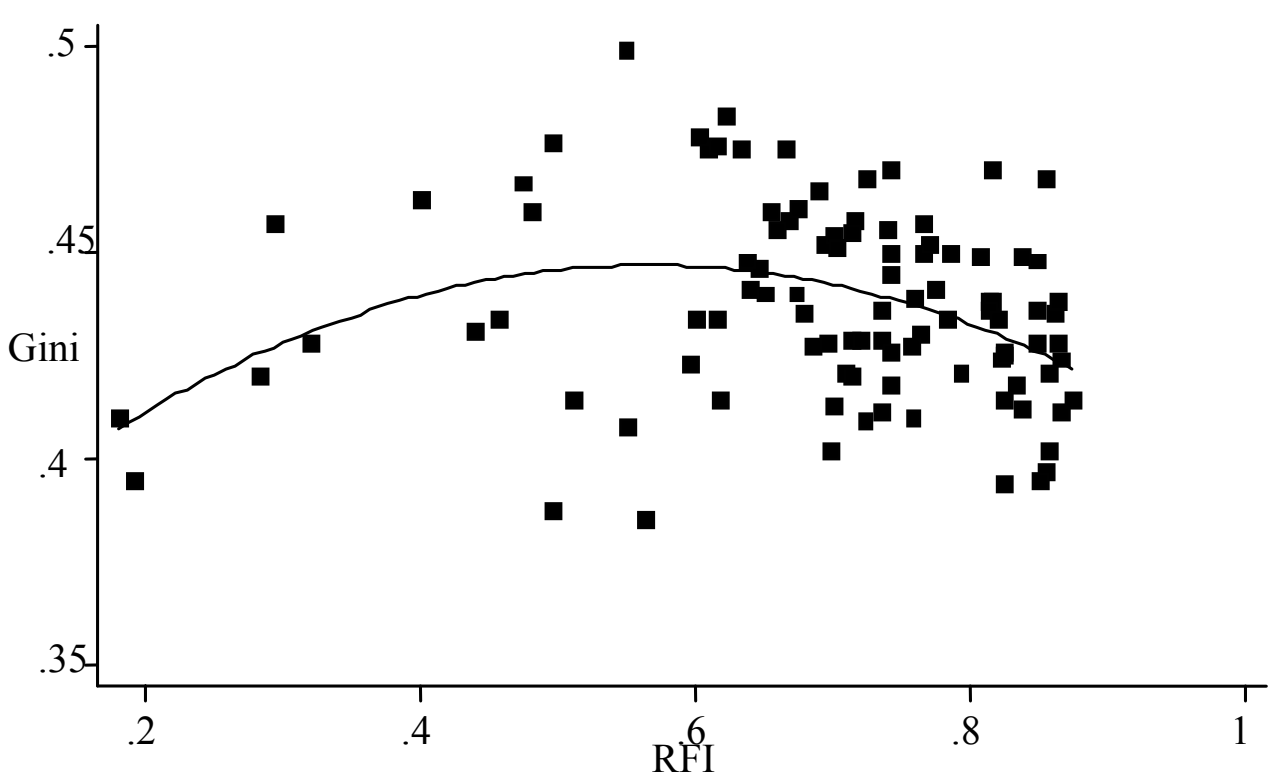

Figure 9. Religious fractionalization and income inequality 


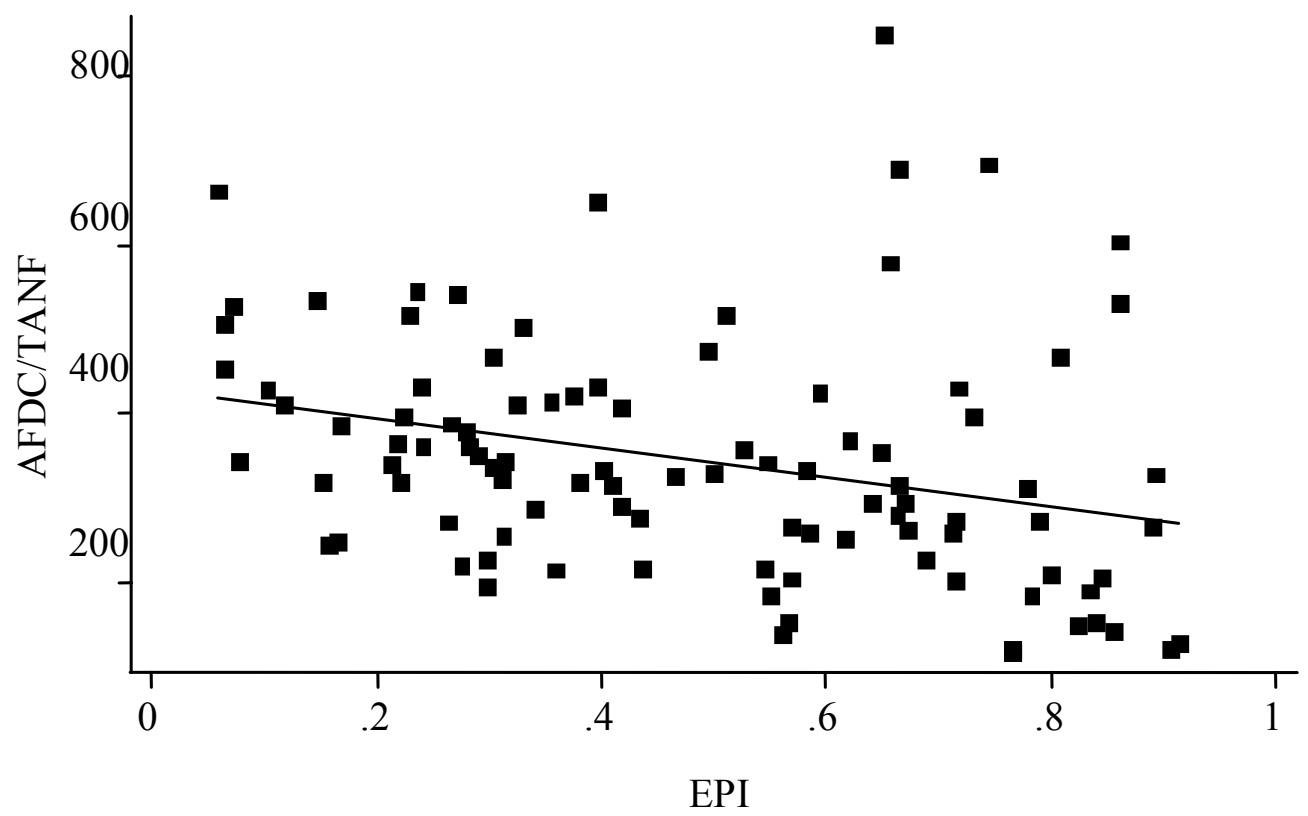

Figure 10. Ethnic polarization and AFDC/TANF

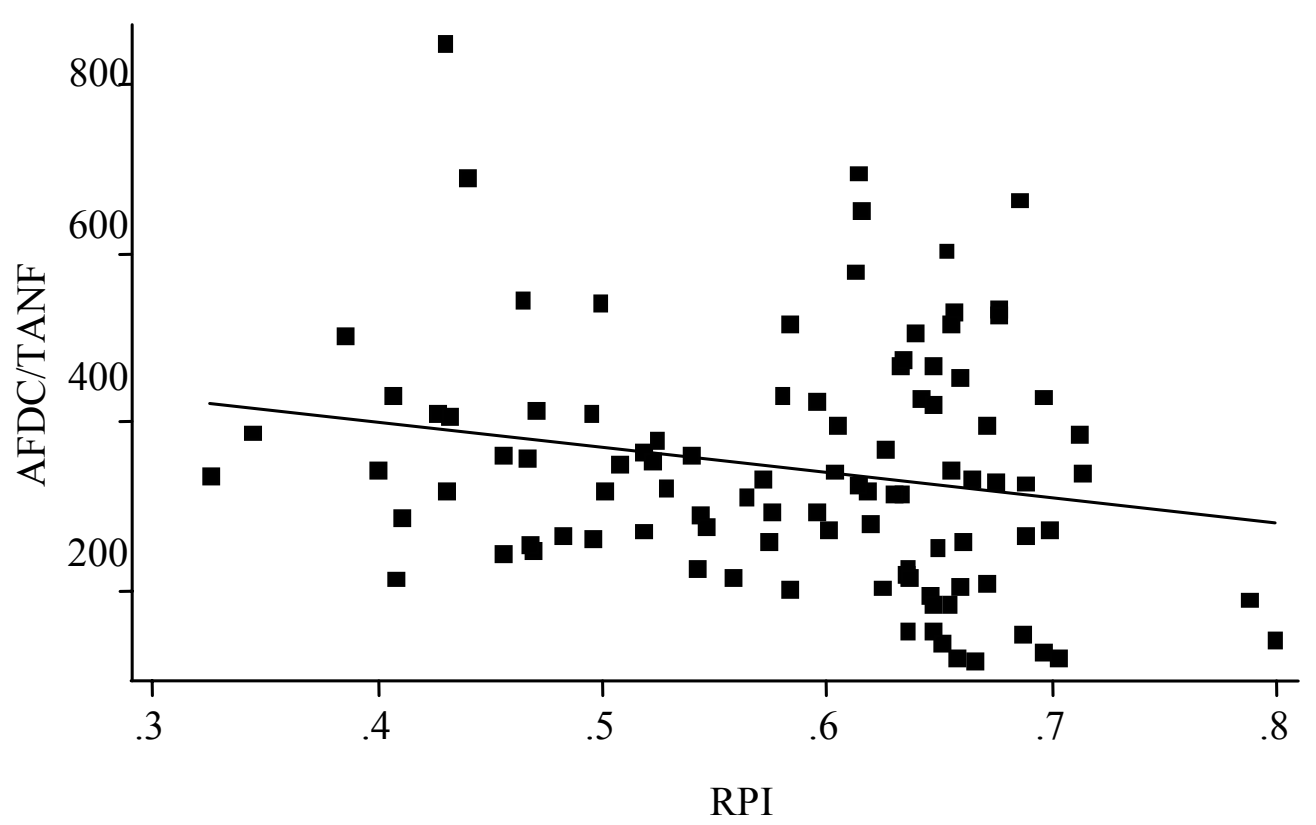

Figure 11. Religious polarization and AFDC/TANF 


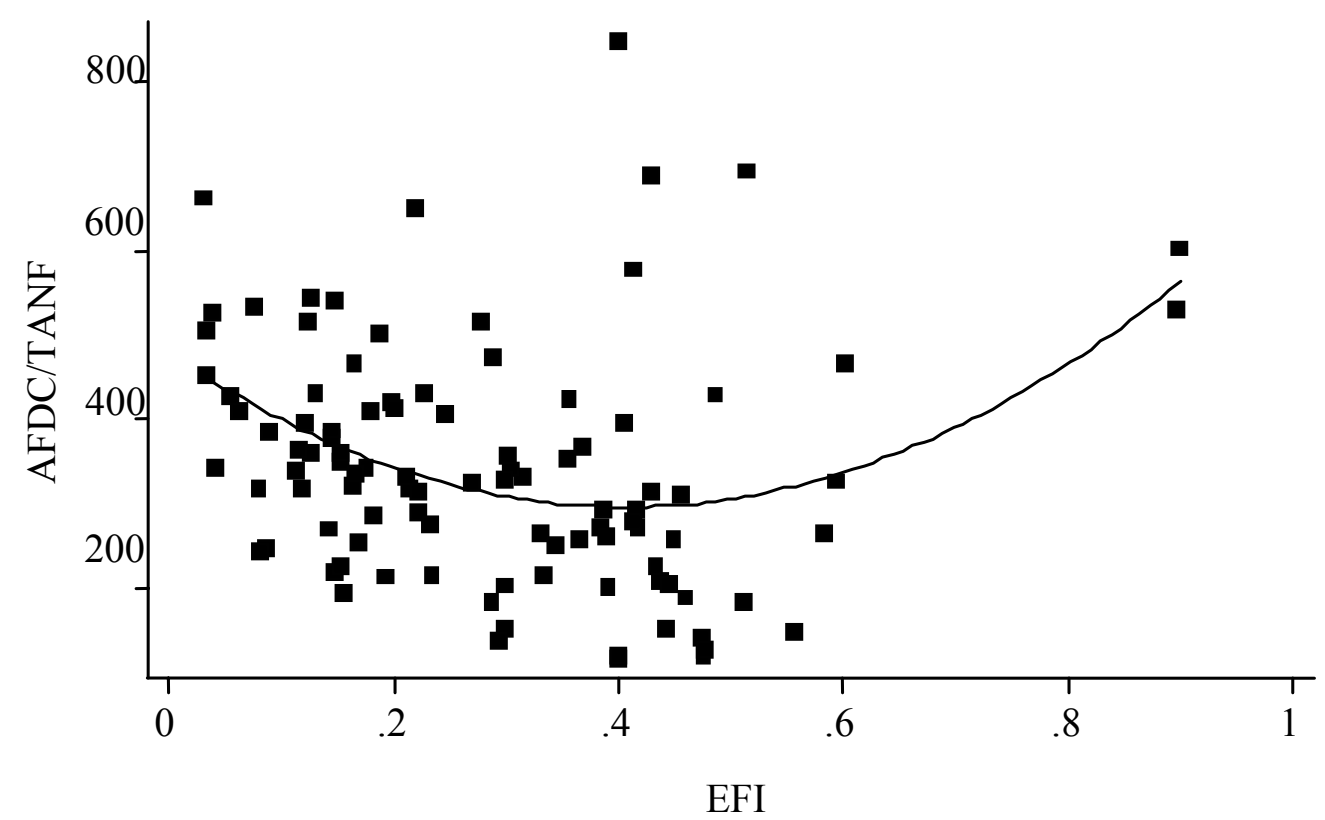

Figure 12. Ethnic fractionalization and AFDC/TANF

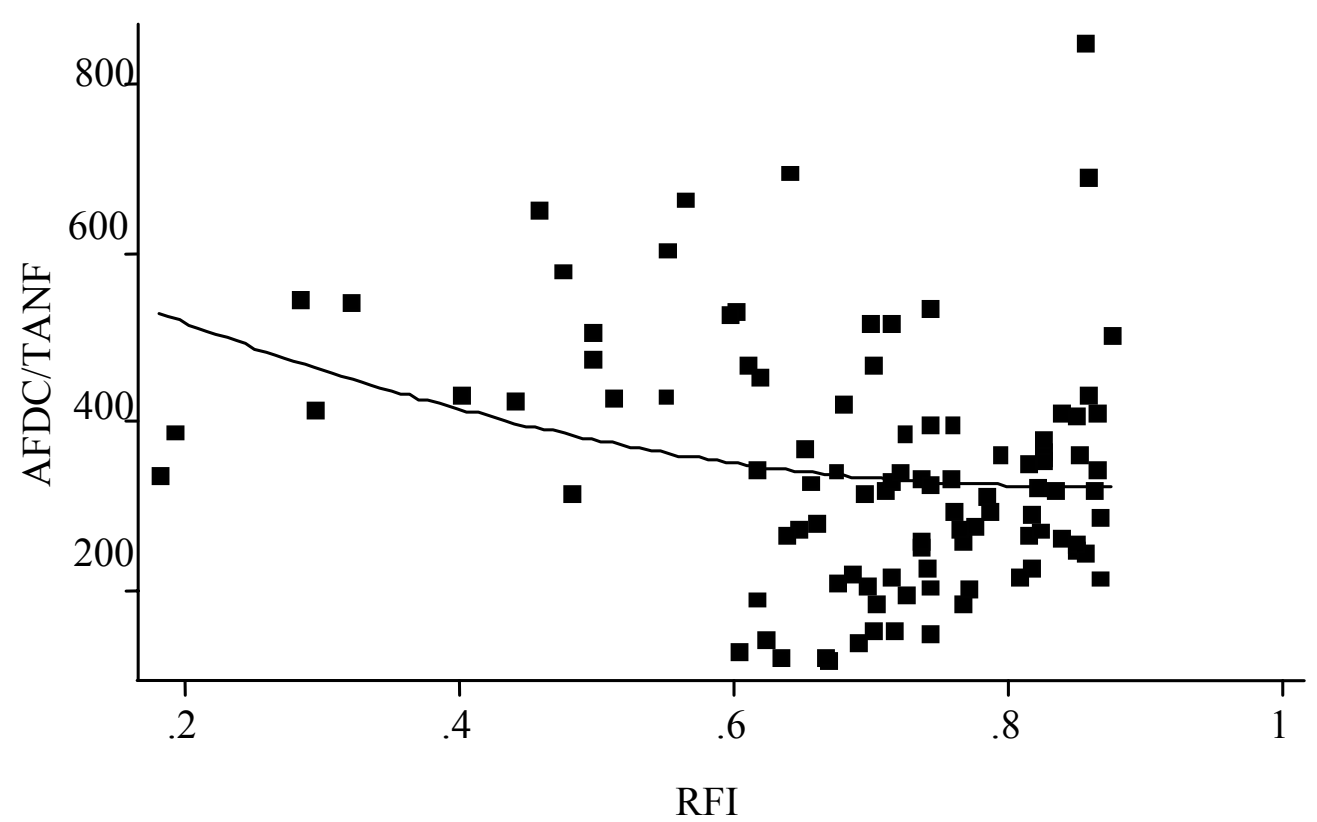

Figure 13. Religious fractionalization and AFDC/TANF 
Table 1. Highest and lowest 5 states

\begin{tabular}{|c|c|c|c|c|c|}
\hline & Gini & $E P I$ & $R P I$ & $E F I$ & RFI \\
\hline \multirow{5}{*}{ 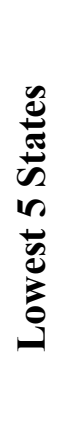 } & Alaska & Vermont & Utah & Vermont & Utah \\
\hline & New Hampshire & Maine & Oregon & Maine & Rhode Island \\
\hline & Utah & New & Washington & New & Massachusetts \\
\hline & Vermont & $\begin{array}{l}\text { Hampshire } \\
\text { Iowa }\end{array}$ & Indiana & $\begin{array}{l}\text { Hampshire } \\
\text { Iowa }\end{array}$ & New Jersey \\
\hline & Wisconsin & West Virginia & Kansas & West Virginia & Connecticut \\
\hline \multirow{5}{*}{ 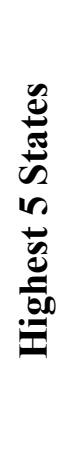 } & New York & Mississippi & Louisiana & Hawaii & Indiana \\
\hline & Louisiana & New Mexico & North Dakota & New Mexico & Kansas \\
\hline & Mississippi & Hawaii & Mississippi & California & Washington \\
\hline & Alabama & Louisiana & New Mexico & Texas & Oregon \\
\hline & Texas & $\begin{array}{l}\text { South } \\
\text { Carolina }\end{array}$ & Georgia & Mississippi & Alaska \\
\hline
\end{tabular}


Table 2. Pairwise correlations of income inequality and heterogeneity measures

\begin{tabular}{lccccc}
\hline & $\boldsymbol{G i n i}$ & $\boldsymbol{E P I}$ & $\boldsymbol{R P I}$ & $\boldsymbol{E F I}$ & $\boldsymbol{R F I}$ \\
\hline $\boldsymbol{G i n i}$ & 1.00 & & & & \\
$\boldsymbol{E P I}$ & 0.55 & 1.00 & & & \\
$\boldsymbol{R P I}$ & 0.39 & 0.36 & 1.00 & & \\
$\boldsymbol{E F I}$ & 0.45 & 0.94 & 0.34 & 1.00 & \\
$\boldsymbol{R F I}$ & -0.08 & -0.02 & -0.18 & -0.06 & 1.00 \\
\hline
\end{tabular}


Table 3. Summary Statistics

\begin{tabular}{|c|c|c|c|c|}
\hline & Mean & Std. Dev. & Min & Max \\
\hline Gini & 0.44 & 0.02 & 0.39 & 0.50 \\
\hline$E P I$ & 0.48 & 0.24 & 0.06 & 0.91 \\
\hline$R P I$ & 0.58 & 0.10 & 0.33 & 0.80 \\
\hline$E F I$ & 0.28 & 0.17 & 0.03 & 0.90 \\
\hline RFI & 0.69 & 0.15 & 0.18 & 0.87 \\
\hline Female Head & 0.11 & 0.02 & 0.07 & 0.17 \\
\hline Young & 0.26 & 0.02 & 0.07 & 0.17 \\
\hline Age & 0.13 & 0.02 & 0.04 & 0.18 \\
\hline College & 0.22 & 0.04 & 0.12 & 0.33 \\
\hline Minimum Wage & 3.68 & 0.30 & 3.35 & 4.84 \\
\hline$A F D C / T A N F$ & 344.63 & 142.10 & 118 & 846 \\
\hline $\begin{array}{c}\text { Unemployment } \\
\text { Insurance }\end{array}$ & 210.63 & 42.86 & 134 & 328.19 \\
\hline $\begin{array}{c}\text { Unemployment } \\
\text { Rate }\end{array}$ & 6.25 & 1.69 & 2.73 & 12.11 \\
\hline Union & 0.14 & 0.06 & 0.03 & 0.30 \\
\hline Corruption & 0.30 & 0.17 & 0.04 & 0.85 \\
\hline GSP Growth & 0.02 & 0.01 & -0.03 & 0.04 \\
\hline
\end{tabular}


Table 4. SUR Estimation: Polarization and Inequality

\begin{tabular}{|c|c|c|c|}
\hline & Gini & Gini & Gini \\
\hline \multirow{2}{*}{ Intercept for the $1980 \mathrm{~s}$} & 0.337 & 0.304 & 0.321 \\
\hline & $(0.042)^{* * *}$ & $(0.044)^{* * *}$ & $(0.044)^{* * *}$ \\
\hline \multirow[t]{2}{*}{ Intercept for the $1990 \mathrm{~s}$} & 0.351 & 0.315 & 0.334 \\
\hline & $(0.043)^{* * *}$ & $(0.045)^{* * *}$ & $(0.045)^{* * *}$ \\
\hline \multirow[t]{2}{*}{$E P I$} & 0.029 & & 0.026 \\
\hline & $(0.011)^{* * *}$ & & $(0.011)^{* *}$ \\
\hline \multirow{2}{*}{$R P I$} & & 0.029 & 0.018 \\
\hline & & $(0.016)^{*}$ & $(0.016)$ \\
\hline \multirow[t]{2}{*}{ Female Head } & 0.259 & 0.443 & 0.259 \\
\hline & $(0.120)^{* *}$ & $(0.092)^{* * *}$ & $(0.119)^{* *}$ \\
\hline \multirow[t]{2}{*}{ Young } & -0.065 & -0.080 & -0.065 \\
\hline & $(0.085)$ & $(0.087)$ & $(0.085)$ \\
\hline \multirow[t]{2}{*}{ Old } & 0.278 & 0.257 & 0.284 \\
\hline & $(0.099)^{* * *}$ & $(0.101)^{* *}$ & $(0.098)^{* * *}$ \\
\hline \multirow[t]{2}{*}{ College } & 0.042 & 0.100 & 0.054 \\
\hline & $(0.049)$ & $(0.047)^{* *}$ & $(0.049)$ \\
\hline \multirow{2}{*}{ Minimum Wage } & 0.004 & 0.004 & 0.004 \\
\hline & $(0.005)$ & $(0.005)$ & $(0.005)$ \\
\hline \multirow[t]{2}{*}{$A F D C / T A N F$} & -0.004 & -0.005 & -0.004 \\
\hline & $(0.002)^{* *}$ & $(0.002)^{* * *}$ & $(0.001)^{* * *}$ \\
\hline \multirow[t]{2}{*}{ Unemployment Insurance } & 0.004 & 0.004 & 0.004 \\
\hline & $(0.003)$ & $(0.003)$ & $(0.003)$ \\
\hline \multirow[t]{2}{*}{ Unemployment Rate } & 0.004 & 0.004 & 0.004 \\
\hline & $(0.001)^{* * *}$ & $(0.001)^{* * *}$ & $(0.001)^{* * *}$ \\
\hline \multirow[t]{2}{*}{ GSP Growth } & -0.099 & -0.106 & -0.101 \\
\hline & $(0.089)$ & $(0.093)^{* *}$ & $(0.090)$ \\
\hline \multirow[t]{2}{*}{ Union } & -0.039 & -0.036 & -0.037 \\
\hline & $(0.034)$ & $(0.034)$ & $(0.033)$ \\
\hline \multirow[t]{2}{*}{ Corruption } & 0.012 & 0.013 & 0.012 \\
\hline & $(0.005)^{* *}$ & $(0.006)^{* *}$ & $(0.006)^{* *}$ \\
\hline \multirow[t]{2}{*}{ South } & -0.009 & -0.003 & -0.007 \\
\hline & $(0.007)$ & $(0.006)$ & $(0.007)$ \\
\hline \multirow[t]{2}{*}{ Midwest } & -0.009 & -0.002 & -0.007 \\
\hline & $(0.006)$ & $(0.006)$ & $(0.006)$ \\
\hline \multirow[t]{2}{*}{ West } & -0.008 & 0.003 & -0.006 \\
\hline & $(0.006)$ & $(0.006)$ & $(0.007)$ \\
\hline Observations & 50,50 & 50,50 & 50,50 \\
\hline R-squared & $0.78,0.74$ & $0.74,0.73$ & $0.77,0.74$ \\
\hline$\rho$ & 0.74 & 0.73 & 0.72 \\
\hline
\end{tabular}


Table 5. SUR Estimation: Fractionalization and Inequality

\begin{tabular}{|c|c|c|c|}
\hline & Gini & Gini & Gini \\
\hline Intercept for the 1980s & $\begin{array}{l}0.329 \\
(0.042)^{* * *}\end{array}$ & $\begin{array}{l}0.295 \\
(0.049)^{* * *}\end{array}$ & $\begin{array}{l}0.305 \\
(0.049) * * *\end{array}$ \\
\hline Intercept for the $1990 \mathrm{~s}$ & $\begin{array}{l}0.344 \\
(0.043)^{* * *}\end{array}$ & $\begin{array}{l}0.306 \\
(0.050) * * *\end{array}$ & $\begin{array}{l}0.319 \\
(0.049) * * *\end{array}$ \\
\hline EFI & $\begin{array}{l}0.095 \\
(0.030) * * *\end{array}$ & & $\begin{array}{l}0.096 \\
(0.030) * * *\end{array}$ \\
\hline$E F I^{2}$ & $\begin{array}{l}-0.077 \\
(0.033)^{* *}\end{array}$ & & $\begin{array}{l}-0.088 \\
(0.033) * *\end{array}$ \\
\hline RFI & & $\begin{array}{l}0.108 \\
(0.057)^{*}\end{array}$ & $\begin{array}{l}0.081 \\
(0.058)\end{array}$ \\
\hline$R F I^{2}$ & & $\begin{array}{l}-0.100 \\
(0.049)^{* *}\end{array}$ & $\begin{array}{l}-0.080 \\
(0.050)\end{array}$ \\
\hline Female Head & $\begin{array}{l}0.261 \\
(0.109)^{* *}\end{array}$ & $\begin{array}{l}0.424 \\
(0.098) * * *\end{array}$ & $\begin{array}{l}0.234 \\
(0.113)^{* *}\end{array}$ \\
\hline Young & $\begin{array}{l}-0.050 \\
(0.084)\end{array}$ & $\begin{array}{l}-0.077 \\
(0.093)\end{array}$ & $\begin{array}{l}-0.059 \\
(0.089)\end{array}$ \\
\hline Old & $\begin{array}{l}0.297 \\
(0.098)^{* * * *}\end{array}$ & $\begin{array}{l}0.261 \\
(0.100) * * *\end{array}$ & $\begin{array}{l}0.318 \\
(0.096) * * *\end{array}$ \\
\hline College & $\begin{array}{l}0.029 \\
(0.048)\end{array}$ & $\begin{array}{l}0.098 \\
(0.047)^{* *}\end{array}$ & $\begin{array}{l}0.045 \\
(0.048)\end{array}$ \\
\hline Minimum Wage & $\begin{array}{l}0.004 \\
(0.005)\end{array}$ & $\begin{array}{l}0.004 \\
(0.005)\end{array}$ & $\begin{array}{l}0.005 \\
(0.005)\end{array}$ \\
\hline$A F D C / T A N F$ & $\begin{array}{l}-0.004 \\
(0.002)^{* *}\end{array}$ & $\begin{array}{l}-0.004 \\
(0.002)^{* *}\end{array}$ & $\begin{array}{l}-0.004 \\
(0.002)^{* *}\end{array}$ \\
\hline Unemployment Insurance & $\begin{array}{l}0.004 \\
(0.003)\end{array}$ & $\begin{array}{l}0.004 \\
(0.003)\end{array}$ & $\begin{array}{l}0.004 \\
(0.003)\end{array}$ \\
\hline Unemployment Rate & $\begin{array}{l}0.004 \\
(0.001)^{* * *}\end{array}$ & $\begin{array}{l}0.004 \\
(0.001)^{* * *}\end{array}$ & $\begin{array}{l}0.004 \\
(0.001) * * *\end{array}$ \\
\hline GSP Growth & $\begin{array}{l}-0.099 \\
(0.089)\end{array}$ & $\begin{array}{l}-0.115 \\
(0.096)\end{array}$ & $\begin{array}{l}-0.133 \\
(0.094)\end{array}$ \\
\hline Union & $\begin{array}{l}-0.040 \\
(0.033)\end{array}$ & $\begin{array}{l}-0.039 \\
(0.034)\end{array}$ & $\begin{array}{l}-0.036 \\
(0.033)\end{array}$ \\
\hline Corruption & $\begin{array}{l}0.012 \\
(0.005)^{* *}\end{array}$ & $\begin{array}{l}0.013 \\
(0.006)^{* *}\end{array}$ & $\begin{array}{l}0.011 \\
(0.005)^{* *}\end{array}$ \\
\hline South & $\begin{array}{l}-0.009 \\
(0.005)\end{array}$ & $\begin{array}{l}0.003 \\
(0.007)\end{array}$ & $\begin{array}{l}-0.003 \\
(0.007)\end{array}$ \\
\hline Midwest & $\begin{array}{l}-0.010 \\
(0.005)^{*}\end{array}$ & $\begin{array}{l}-0.000 \\
(0.007)\end{array}$ & $\begin{array}{l}-0.004 \\
(0.007)\end{array}$ \\
\hline West & $\begin{array}{l}-0.009 \\
(0.006)\end{array}$ & $\begin{array}{l}0.004 \\
(0.007)\end{array}$ & $\begin{array}{l}-0.002 \\
(0.007)\end{array}$ \\
\hline Observations & 50,50 & 50,50 & 50,50 \\
\hline R-squared & $0.77,0.75$ & $0.75,0.73$ & $0.79,0.76$ \\
\hline$\rho$ & 0.72 & 0.74 & 0.72 \\
\hline
\end{tabular}


Table 6. SUR Estimation: Polarization and AFDC/TANF

\begin{tabular}{llll}
\hline & AFDC/TANF & AFDC/TANF & AFDC/TANF \\
\hline Intercept for the 1980s & 344.556 & 370.605 & 322.316 \\
& $(243.388)$ & $(275.668)$ & $(260.270)$ \\
Intercept for the 1990s & 246.382 & 277.283 & 231.164 \\
& $(248.698)$ & $(279.893)$ & $(264.245)$ \\
EPI & -196.457 & & -188.161 \\
& $(47.091)^{* * *}$ & & $(50.937)^{* * *}$ \\
$\boldsymbol{R P I}$ & & -207.863 & -43.323 \\
& & $(114.199)^{*}$ & $(114.247)$ \\
Young & -601.359 & -783.149 & -529.747 \\
& $(497.329)$ & $(545.334)$ & $(505.900)$ \\
Old & -1056.288 & -429.607 & -949.779 \\
& $(712.196)$ & $(761.391)$ & $(719.099)$ \\
Median Income $\left(\mathbf{1 0 0}^{2}\right)$ & 1106.86 & 744.920 & 880.780 \\
& $(265.550)^{* * *}$ & $(225.44)^{* * *}$ & $(209.260)^{* * *}$ \\
Union & 640.619 & 737.484 & 642.112 \\
& $(195.524)^{* * *}$ & $(214.099)^{* * *}$ & $(195.789)^{* * *}$ \\
Observations & 50,50 & 50,50 & 50,50 \\
R-squared & $0.67,0.54$ & $0.55,0.47$ & $0.67,0.54$ \\
$\rho$ & 0.83 & 0.84 & 0.82 \\
\hline Robust standard errors in parentheses $*$ significant at 10\%; $* *$ significant at 5\%; $* * *$ significant at $1 \%$.
\end{tabular}


Table 7. SUR Estimation: Fractionalization and AFDC/TANF

\begin{tabular}{|c|c|c|c|}
\hline & $A F D C / T A N F$ & $A F D C / T A N F$ & $A F D C / T A N F$ \\
\hline Intercept for the 1980s & $\begin{array}{l}394.190 \\
(236.134)^{*}\end{array}$ & $\begin{array}{l}518.962 \\
(311.021)^{*}\end{array}$ & $\begin{array}{l}529.301 \\
(284.589)\end{array}$ \\
\hline Intercept for the $1990 \mathrm{~s}$ & $\begin{array}{l}305.429 \\
(239.465)\end{array}$ & $\begin{array}{l}428.429 \\
(316.067)\end{array}$ & $\begin{array}{l}441.761 \\
(288.514)\end{array}$ \\
\hline$E F I$ & $\begin{array}{l}-817.320 \\
(173.482)^{* * *}\end{array}$ & & $\begin{array}{l}-789.540 \\
(176.613)^{* * *}\end{array}$ \\
\hline$E F I^{2}$ & $\begin{array}{l}820.225 \\
(218.248)^{* * *}\end{array}$ & & $\begin{array}{l}864.577 \\
(220.231)^{* * *}\end{array}$ \\
\hline RFI & & $\begin{array}{l}-783.815 \\
(429.806) *\end{array}$ & $\begin{array}{l}-379.354 \\
(406.918)\end{array}$ \\
\hline$R F I^{2}$ & & $\begin{array}{l}617.469 \\
(353.756)^{*}\end{array}$ & $\begin{array}{l}305.236 \\
(336.981)\end{array}$ \\
\hline Young & $\begin{array}{l}-616.600 \\
(495.665)\end{array}$ & $\begin{array}{l}-865.171 \\
(547.953)\end{array}$ & $\begin{array}{l}-696.619 \\
(506.198)\end{array}$ \\
\hline Old & $\begin{array}{l}-1024.054 \\
(682.560)\end{array}$ & $\begin{array}{l}-471.726 \\
(762.905)\end{array}$ & $\begin{array}{c}-1023.389 \\
(686.187)\end{array}$ \\
\hline Median Income $\left(100^{2}\right)$ & $\begin{array}{l}837.400 \\
(195.040)^{* * *}\end{array}$ & $\begin{array}{l}699.260 \\
(234.530) * * *\end{array}$ & $\begin{array}{l}796.980 \\
(207.530) * * *\end{array}$ \\
\hline Union & $\begin{array}{l}620.567 \\
(190.776)^{* * *}\end{array}$ & $\begin{array}{l}780.451 \\
(215.685)^{* * *}\end{array}$ & $\begin{array}{l}643.042 \\
(192.844) * * *\end{array}$ \\
\hline Observations & 50,50 & 50,50 & 50,50 \\
\hline R-squared & $0.67,0.61$ & $0.55,0.48$ & $0.66,0.62$ \\
\hline$\rho$ & 0.82 & 0.85 & 0.82 \\
\hline
\end{tabular}

